\title{
Optimization of $\beta$-Glucosidase, $\beta$-Xylosidase and Xylanase Production by Colletotrichum graminicola under Solid-State Fermentation and Application in Raw Sugarcane Trash Saccharification
}

Ana L. R. L. Zimbardi ${ }^{1}$, Cesar Sehn ${ }^{1}$, Luana P. Meleiro ${ }^{1}$, Flavio H. M. Souza ${ }^{1}$, Douglas C. Masui ${ }^{2}$, Monica S. F. Nozawa ${ }^{3}$, Luis H. S. Guimarães ${ }^{2}$, João A. Jorge ${ }^{2}$ and Rosa P. M. Furriel ${ }^{1, *}$

1 Department of Chemistry, Faculty of Philosophy, Sciences and Languages of Ribeirão Preto, University of SãoPaulo, Bandeirantes Avenue, 3900, Ribeirão Preto, SP 14040-901, Brazil; E-Mails: luccilatorre@usp.br (A.L.R.L.Z.); cesar.sehn@hotmail.com (C.S.); luanapm@aluno.ffclrp.usp.br (L.P.M.); flaviosouza@usp.br (F.H.M.S.)

2 Department of Biology, Faculty of Philosophy, Sciences and Languages of Ribeirão Preto, University of São Paulo, Bandeirantes Avenue, 3900, Ribeirão Preto, SP 14040-901, Brazil; E-Mails: dcmasui@usp.br (D.C.M.); lhguimaraes@ffclrp.usp.br (L.H.S.G.); joajorge@ffclrp.usp.br (J.A.J.)

3 Laboratory of Gene Expression and Microbiology, Department of Graduation, University Nilton Lins, Prof. Nilton Lins Avenue, 3259, Manaus, AM 69058-040, Brazil; E-Mail: profmonica.nozawa@gmail.com

* Author to whom correspondence should be addressed; E-Mail: rosapmfi@ffclrp.usp.br; Tel.: +55-16-3602-3749; Fax: +55-16-3602-4838.

Received: 5 September 2012; in revised form: 12 December 2012 / Accepted: 9 January 2013 / Published: 30 January 2013

Abstract: Efficient, low-cost enzymatic hydrolysis of lignocellulosic residues is essential for cost-effective production of bioethanol. The production of $\beta$-glucosidase, $\beta$-xylosidase and xylanase by Colletotrichum graminicola was optimized using Response Surface Methodology (RSM). Maximal production occurred in wheat bran. Sugarcane trash, peanut hulls and corncob enhanced $\beta$-glucosidase, $\beta$-xylosidase and xylanase production, respectively. Maximal levels after optimization reached $159.3 \pm 12.7 \mathrm{U} \mathrm{g} \mathrm{g}^{-1}, 128.1 \pm 6.4 \mathrm{U} \mathrm{g}^{-1}$ and $378.1 \pm 23.3 \mathrm{U} \mathrm{g}^{-1}$, respectively, but the enzymes were produced simultaneously at good levels under culture conditions optimized for each one of them. Optima of $\mathrm{pH}$ and temperature were 5.0 and $65{ }^{\circ} \mathrm{C}$ for the three enzymes, which maintained full activity for $72 \mathrm{~h}$ at $50{ }^{\circ} \mathrm{C}$ and for $120 \mathrm{~min}$ at $60{ }^{\circ} \mathrm{C}$ ( $\beta$-glucosidase) or $65{ }^{\circ} \mathrm{C}$ ( $\beta$-xylosidase and 
xylanase). Mixed with Trichoderma reesei cellulases, C. graminicola crude extract hydrolyzed raw sugarcane trash with glucose yield of $33.1 \%$ after $48 \mathrm{~h}$, demonstrating good potential to compose efficient cocktails for lignocellulosic materials hydrolysis.

Keywords: $\beta$-glucosidase; $\beta$-xylosidase; xylanase; Colletotrichum graminicola; sugarcane trash hydrolysis

\section{Introduction}

Recent years have seen an ever-increasing interest in cellulose and hemicellulose hydrolysis, in an effort to develop a cost-effective process to use lignocellulosic residues as raw materials for the production of value added products, mainly bioethanol [1-3]. In Brazil, a great producer of bioethanol from sugarcane by conventional processes, sugarcane bagasse and trash (cane leaves and tops) appear as attractive options for cellulosic ethanol production. Besides their low cost, these residues are produced in huge amounts at or near the mills, thus reducing transport and infrastructural costs for further processing [4,5]. Usually, most sugarcane bagasse is burned to produce steam to run the plant, and for bioelectricity generation [6]. In contrast, sugarcane trash (SCT), estimated as $140 \mathrm{~kg}$ (dry) per sugarcane ton processed, is left in the field after mechanical sugarcane harvesting [4,5]. Thus, although the maintenance of $40 \%-50 \%$ SCT in the field is recommended for soil conservation and disease control [7], the surplus is now considered a promising source for second-generation ethanol production.

The enzymatic treatment is considered the most promising method for an efficient hydrolysis of cellulose in lignocellulosic residues [3,8-10]. However, the high cost of cellulolytic enzymes $[1,8,10,11]$ remains a major bottleneck for cellulosic ethanol production. Moreover, due to the recalcitrance of the lignocellulosic matrix to enzymatic hydrolysis [1,9], costly physicochemical pre-treatments are often necessary $[1-3,12]$.

During the last few years, researchers' interest has been mostly focused on cellulases and cellulase-based cocktails for cellulose hydrolysis. However, it is now well known that enzymatic cocktails containing both cellulases and hemicellulases are required for an efficient saccharification of cellulose in lignocellulosic residues, resulting in higher yields of fermentable sugars with lower enzyme loads $[8,10,13,14]$. Xylan is the main hemicellulose in agricultural residues, and its removal from the outer surface of the cellulosic fibers by xylanases evidently improves the accessibility of the cellulose chains to cellulases. The more efficient hydrolysis of cellulose then leads to an enhanced exposure of the xylan chains entrapped between cellulosic fibers to the action of xylanases [10]. Additionally, some studies have also shown that xylan and xyloligosaccharides are potent inhibitors of cellulases [13]. Consequently, there is currently a growing interest in low-cost, efficient xylan-degrading enzymes.

Cellulose enzymatic hydrolysis requires the synergistic action of endo-1,4- $\beta$-glucanases (EC 3.2.1.4), exo-1,4- $\beta$-glucanases or cellobiohydrolases (EC 3.2.1.91), and 1,4- $\beta$-glucosidases (EC 3.2.1.21). Endoglucanases randomly cleave internal glycosidic linkages in cellulosic chains, while exoglucanases liberate cellobiose from their edges. $\beta$-glucosidases then act on celloligosaccharides and cellobiose, liberating glucose [9]. Since most glucanases are inhibited by cellobiose and short 
cellooligosaccharides, $\beta$-glucosidases catalyze the rate-limiting step of the cellulose hydrolysis process as a whole $[15,16]$. Owing to its higher structural complexity, xylan saccharification involves two principal enzymes and several accessory ones. Endo- $\beta$-1,4-xylanases (EC 3.2.1.8) randomly cleave $\beta$-1,4-glycosidic linkages in the xylan main chain, releasing xylooligosaccharides, while $\beta$-xylosidases (EC 3.2.1.37) release xylose from xylobiose and xylooligosaccharides. Like glucanases, xylanases are also usually inhibited by xylobiose and short xyloligosaccharides, and $\beta$-xylosidases are then responsible for the rate-limiting step of xylan hydrolysis. Accessory enzymes, including $\alpha$-L-arabinofurosidase (EC 3.2.1.55), remove side groups from the xylan main chain $[17,18]$.

Most commercial cellulases and hemicellulases are currently produced by fungi under submerged fermentation. However, solid-state fermentation (SSF) is increasingly being considered an ideal, cost-effective technology for the production of cellulolytic enzymes. SSF conditions mimic the natural environment of fungi, resulting in higher fermentation productivity. Further, cellulases and hemicellulases produced under SSF are often more thermostable and pH-resistant [1,19-21]. On the other hand, low-cost agroindustrial residues may be used as carbon sources, and effluent generation and demands on energy and sterile water are lower. Moreover, the enzymes are obtained at higher concentrations, reducing downstream processing. Since purity is not a pre-requisite for various industrial applications, crude enzyme extracts may then be directly employed [11,19-21]. Altogether, these advantages result in about ten times less production costs, and the optimization of culture conditions may still improve the economic viability of SSF processes [19,21].

The filamentous fungi from the genus Colletotrichum and their teleomorph Glomerella are recognized as one of the most important plant pathogens distributed on earth, particularly in tropical and subtropical regions. Colletotrichum causes plant diseases, usually known as antracnoses. Although different species from this genus are considered models for genetic and physiological studies [22], their potential for enzyme production is unexploited to date. A strain of Colletotrichum graminicola was isolated from the Amazon soil, and preliminary studies revealed that it had good potential for the production of $\beta$-glucosidases, xylanases and $\beta$-xylosidases under SSF, but secreted low levels of cellulases. Thus, crude culture extracts from this strain, supplemented with cellulases, could be interesting for the hydrolysis of lignocellulosic residues, such as SCT.

Trichoderma reesei is the best-known cellulase producer among filamentous fungi, and the preferred organism for the production of industrial cellulases [23,24]. The cellulolytic system of T. reesei has been extensively investigated. It produces good levels of two cellobiohydrolases (CBH1 and $\mathrm{CBH} 2$ ) and at least four endoglucanases (EG1, EG2, EG3, EG5), but low levels of two $\beta$-glucosidases (BGLI and BGLII). Thus, cellulose treatment with $T$. reesei crude culture extracts without an additional load of $\beta$-glucosidase results in the accumulation of cellobiose and consequent inhibition of endo- and exo-cellulases, with low glucose yields [15,25].

In this study we optimized the production of $\beta$-glucosidase, $\beta$-xylosidase and xylanase by a newly isolated strain of $C$. graminicola under SSF in low-cost media constituted of agroindustrial byproducts and/or residues. The efficiency of the crude culture extract from C. graminicola alone or in mixture with $T$. reesei crude cellulases for the hydrolysis of sugarcane trash without pre-treatment (RSCT) was also investigated. 


\section{Results and Discussion}

\subsection{Preliminary Screening for the Best Carbon Sources and Supplementary Nitrogen and Carbon} Sources for Enzymes Production by C. graminicola

The best carbon source for $\beta$-glucosidase production was wheat bran (Table 1). The levels of enzyme reached $109.7 \pm 7.7 \mathrm{U} \mathrm{g}^{-1}$ dry substrate and the fungus showed vigorous growth in this substrate. Good enzyme levels were also obtained in peanut hulls, corn and rice husks. Although the fungus grew poorly in SCT, with a low enzyme production, the supplementation of wheat bran with $1 \%(w / w)$ SCT resulted in 1.6-fold increase in enzyme production levels. Enhanced production (1.4-fold) also resulted from wheat bran supplementation with $1 \%(w / w)$ cellobiose, but filter paper and carboxymethylcellulose (CMC) showed negligible effects. Addition of organic and inorganic nitrogen sources to wheat bran inhibited $\beta$-glucosidase production, except for yeast extract and soybean meal, without effect (Table 1).

Maximal levels of $\beta$-xylosidase were obtained in wheat bran $\left(57.9 \pm 4.6 \mathrm{U} \mathrm{g}^{-1}\right)$, but milled corncob, soybean meal and corn husks were also acceptable sources for enzyme production (Table 1). Wheat bran supplementation with $1 \%$ peanut hulls increased the production by $42 \%$. Various supplementary carbon sources, including xylan, were somewhat inhibitory, and $1 \%$ glucose, xylose or cellobiose reduced the enzyme production by about $40 \%$. Most supplementary nitrogen sources inhibited $\beta$-xylosidase production, except for casein and yeast extract, without effect (Table 1).

Wheat bran was also the best carbon source for xylanase production, reaching $189.3 \pm 9.5 \mathrm{U} \mathrm{g}^{-1}$, and low to negligible enzyme levels were obtained in all other carbon sources (Table 1). Wheat bran supplementation with $1 \%$ milled corncob slightly enhanced xylanase production. Most other supplementary carbon sources tested, including xylan, were without effect, while xylose inhibited about $33 \%$ the production of the enzyme. The addition of $0.8 \%\left(\mathrm{NH}_{4}\right)_{2} \mathrm{SO}_{4}$ and $1 \%$ peptone to wheat bran increased xylanase production (30\% and $20 \%$, respectively), while all other nitrogen sources tested inhibited the production, except for casein (Table 1).

Several studies show that wheat bran is a good carbon source for the production of lignocellulolytic enzymes by different fungi under SSF, even in the absence of any supplementary carbon or nitrogen source [26-29]. This has been attributed to its particularly rich nutritional composition: vitamin B, about $14 \%$ proteins, $27 \%$ carbohydrates (64\% cellulose and $36 \%$ hemicellulose), $6 \%$ lipids, $5 \%$ minerals, and around $64 \%$ digestible nitrogen [30,31].

Table 1. Effect of different carbon sources on $\beta$-glucosidase, $\beta$-xylosidase and xylanase production by $C$. graminicola under solid-state fermentation.

\begin{tabular}{cccc}
\hline Carbon Source & $\boldsymbol{\beta}$-glucosidase $\left(\mathbf{U ~ g}^{-\mathbf{1}}\right)$ & $\boldsymbol{\beta}$-xylosidase $\left(\mathbf{U ~ g ~}^{-\mathbf{1}}\right)$ & Xylanase $\left(\mathbf{U ~ g}^{\mathbf{- 1}}\right)$ \\
\hline Wheat bran & $109.7 \pm 7.7$ & $57.9 \pm 4.6$ & $189.3 \pm 9.5$ \\
Steam-exploded sugarcane bagasse & $9.5 \pm 1.1$ & $15.9 \pm 1.4$ & $\mathrm{ND}^{\mathrm{a}}$ \\
Raw sugarcane bagasse & $20.8 \pm 1.8$ & $6.9 \pm 0.8$ & $11.4 \pm 1.1$ \\
Sugarcane trash & $10.2 \pm 1.2$ & $11.5 \pm 1.3$ & $15.7 \pm 1.6$ \\
Peanut hull & $57.0 \pm 4.1$ & $9.4 \pm 1.2$ & $6.4 \pm 0.7$ \\
Rice husk & $47.5 \pm 4.1$ & $13.6 \pm 1.5$ & $9.6 \pm 1.2$ \\
Corn husk & $48.3 \pm 3.9$ & $24.7 \pm 2.4$ & $\mathrm{ND}$ \\
Milled corncob & - & $37.8 \pm 3.3$ & $15.7 \pm 1.8$ \\
\hline
\end{tabular}


Table 1. Cont.

\begin{tabular}{|c|c|c|c|c|c|c|c|}
\hline \multirow{2}{*}{\multicolumn{2}{|c|}{$\begin{array}{c}\text { Carbon Supplement } \\
(1 \% w / w)\end{array}$}} & \multicolumn{2}{|c|}{$\beta$-glucosidase } & \multicolumn{2}{|c|}{$\beta$-xylosidase } & \multicolumn{2}{|c|}{ Xylanase } \\
\hline & & $\mathrm{U} \mathrm{g}^{-1}$ & $\%$ & $\mathrm{U} \mathrm{g}^{-1}$ & $\%$ & $\mathrm{Ug}^{-1}$ & $\%$ \\
\hline \multicolumn{2}{|l|}{ None } & $101.1 \pm 7.8$ & 100.0 & $55.5 \pm 5.1$ & 100 & $193.2 \pm 13.8$ & 100 \\
\hline \multicolumn{2}{|c|}{ Peanut hull } & $49.2 \pm 4.6$ & 48.7 & $79.0 \pm 7.7$ & 142.3 & $178.0 \pm 11.3$ & 92.1 \\
\hline \multicolumn{2}{|c|}{ Rice husk } & $33.6 \pm 3.2$ & 33.2 & $49.4 \pm 5.1$ & 89.0 & $176.1 \pm 12.3$ & 91.1 \\
\hline \multicolumn{2}{|c|}{ Corn husk } & $54.9 \pm 5.3$ & 54.0 & $38.8 \pm 3.9$ & 69.9 & $205.6 \pm 14.3$ & 106.4 \\
\hline \multicolumn{2}{|c|}{ Milled corncob } & - & - & $47.5 \pm 4.8$ & 85.6 & $239.8 \pm 15.2$ & 124.1 \\
\hline \multicolumn{2}{|c|}{ Sugarcane trash } & $162.9 \pm 13.1$ & 161.1 & $40.2 \pm 4.1$ & 72.4 & $178.4 \pm 10.9$ & 92.3 \\
\hline \multicolumn{2}{|c|}{ Filter paper } & $97.9 \pm 8.4$ & 96.8 & $43.9 \pm 3.8$ & 79.1 & $189.5 \pm 12.9$ & 98.1 \\
\hline \multicolumn{2}{|c|}{ Glucose } & $91.4 \pm 8.4$ & 90.4 & $35.5 \pm 4.3$ & 64.0 & $231.8 \pm 15.3$ & 120.0 \\
\hline \multicolumn{2}{|c|}{ Xylose } & - & - & $34.7 \pm 4.5$ & 62.5 & $129.5 \pm 10.4$ & 67.0 \\
\hline \multicolumn{2}{|c|}{ Celobiose } & $144.8 \pm 10.4$ & 143.2 & $34.0 \pm 4.2$ & 61.3 & $173.4 \pm 14.9$ & 89.7 \\
\hline \multicolumn{2}{|l|}{$\mathrm{CMC}$} & $84.8 \pm 7.6$ & 83.9 & $48.3 \pm 4.2$ & 87.0 & $171.6 \pm 13.4$ & 88.8 \\
\hline \multicolumn{2}{|l|}{ Xylan } & - & - & $42.1 \pm 3.9$ & 75.8 & $204.5 \pm 15.4$ & 105.8 \\
\hline \multirow{2}{*}{$\begin{array}{c}\text { Nitrogen } \\
\text { Supplement }\end{array}$} & \multirow{2}{*}{$\begin{array}{c}\% \\
(w / w)\end{array}$} & \multicolumn{2}{|c|}{$\beta$-glucosidase } & \multicolumn{2}{|c|}{$\beta$-xylosidase } & \multicolumn{2}{|c|}{ Xylanase } \\
\hline & & $\mathrm{Ug}^{-1}$ & $\%$ & $\mathrm{U} \mathrm{g}^{-1}$ & $\%$ & $\mathrm{Ug}^{-1}$ & $\%$ \\
\hline None & - & $92.5 \pm 8.9$ & 100.0 & $47.8 \pm 5.2$ & 100 & $152.7 \pm 12.2$ & 100 \\
\hline Asparagine & 1 & $42.4 \pm 5.1$ & 45.8 & $38.8 \pm 4.2$ & 81.2 & $118.5 \pm 10.7$ & 77.6 \\
\hline Glycine & 1 & $35.4 \pm 4.6$ & 38.3 & $37.1 \pm 4.3$ & 77.6 & $124.2 \pm 11.0$ & 81.3 \\
\hline Casein & 1 & $39.7 \pm 4.8$ & 42.9 & $47.4 \pm 5.1$ & 99.1 & $151.3 \pm 11.7$ & 99.1 \\
\hline Peptone & 1 & $40.4 \pm 5.2$ & 43.7 & $36.1 \pm 4.0$ & 75.5 & $182.7 \pm 13.7$ & 119.6 \\
\hline Yeast extract & 1 & $88.4 \pm 7.9$ & 95.6 & $43.9 \pm 4.8$ & 91.8 & $164.1 \pm 12.8$ & 107.5 \\
\hline Malt extract & 1 & $41.6 \pm 4.6$ & 45.0 & $27.2 \pm 3.4$ & 56.9 & $129.9 \pm 11.2$ & 85.1 \\
\hline Soybean meal & 1 & $87.5 \pm 9.6$ & 94.6 & $37.7 \pm 4.2$ & 78.9 & $127.0 \pm 11.6$ & 83.2 \\
\hline Urea & 0.8 & $39.9 \pm 3.2$ & 43.1 & $19.5 \pm 2.8$ & 40.8 & $97.1 \pm 8.7$ & 63.6 \\
\hline $\mathrm{NH}_{4} \mathrm{NO}_{3}$ & 0.8 & $40.9 \pm 3.7$ & 44.2 & $23.9 \pm 3.1$ & 50.0 & $125.6 \pm 11.3$ & 82.2 \\
\hline $\mathrm{KNO}_{3}$ & 0.8 & $41.7 \pm 4.2$ & 45.1 & $21.1 \pm 2.6$ & 44.1 & $131.3 \pm 11.0$ & 86.0 \\
\hline $\mathrm{NaNO}_{3}$ & 0.8 & $38.9 \pm 4.3$ & 42.0 & $26.5 \pm 3.1$ & 55.4 & $122.7 \pm 10.2$ & 80.3 \\
\hline$\left(\mathrm{NH}_{4}\right)_{2} \mathrm{SO}_{4}$ & 0.8 & $44.7 \pm 4.0$ & 48.3 & $23.7 \pm 2.7$ & 49.6 & $198.4 \pm 13.5$ & 129.9 \\
\hline $\mathrm{NH}_{4} \mathrm{Cl}$ & 0.8 & $40.7 \pm 3.7$ & 44.0 & $32.9 \pm 3.6$ & 68.8 & $125.6 \pm 11.3$ & 82.2 \\
\hline
\end{tabular}

Notes: Colletotrichum graminicola was cultured for $192 \mathrm{~h}$ at $25{ }^{\circ} \mathrm{C}$ in $5 \mathrm{~g}$ dry carbon source (or a mass occupying maximally $1 / 5$ of the total volume of the culture flask) and deionized water ( $2 \mathrm{~mL} \mathrm{~g}^{-1}$ dry substrate). Supplementary nitrogen and carbon sources were added to wheat bran as carbon source at the indicated concentrations. Enzymatic assays were performed in duplicate; each experiment was repeated using four different crude extracts $(n=4)$. Data are presented as means $\pm \mathrm{SD} ;{ }^{a} \mathrm{ND}$ : undetectable by the methods used.

\subsection{Optimization of Enzyme Production by C. graminicola Using Response Surface Methodology (RSM)}

The optimization of culture media by varying one independent variable at a time maintaining the others at constant levels (OFAT) results in considerable increases in enzyme productivity by microorganisms. However, besides being expensive and time consuming, this methodology does not show the interactions that may occur between different variables that affect enzyme production. In contrast, statistical approaches using response surface methodology not only allow the identification of the optimal conditions by a set of independent variables, but also reveal the interactions between two or more variables [32]. 
After preliminary studies by OFAT to define the experimental ranges for each independent variable, the culture conditions for the production of $\beta$-glucosidase, $\beta$-xylosidase and xylanase were optimized using a Central Composite Rotational Design (CCRD).

Data obtained for each enzyme (Tables 2-4) were analyzed by multiple regression analysis, and the predicted responses for $\beta$-glucosidase ( $\beta \mathrm{glu}), \beta$-xylosidase ( $\beta \mathrm{xyl})$ and xylanase (Xyl) production were:

$$
\begin{gathered}
\beta \mathrm{glu}=182.91-7.39 x+11.41 y+17.47 z-9.45 x^{2}-66.88 y^{2}-32.69 z^{2} \\
\beta \mathrm{xyl}=-1732.78+376.92 y+359.70 z-5.51 w-21.76 y^{2}-48.12 z^{2}-3.56 w^{2}-4.00 y z-5.14 w z \\
\mathrm{Xyl}=373.94-36.80 x+61.96 y+91.43 z-3.65 k-24.45 s-195.67 x^{2}-113.16 y^{2}-112.32 z^{2}- \\
26.04 k^{2}-35.44 s^{2}+40.33 x z
\end{gathered}
$$

where $x, y, z, w, k$ and $s$ were the coded values for temperature, culture time, initial moisture, peanut hulls, milled corncob and $\left(\mathrm{NH}_{4}\right)_{2} \mathrm{SO}_{4}$ concentrations, respectively.

Table 2. Experimental conditions and results of the statistical experimental design for $\beta$-glucosidase production by $C$. graminicola.

\begin{tabular}{ccccc}
\hline \multirow{2}{*}{ Run } & \multicolumn{4}{c}{ Real(Coded) values } \\
\cline { 2 - 5 } & $\boldsymbol{x}$ & $\boldsymbol{y}$ & $\boldsymbol{z}$ & $\boldsymbol{\beta}$-glucosidase ${ }^{\mathbf{a}}\left(\mathbf{U ~ g}^{\mathbf{- 1}} \mathbf{)}\right.$ \\
\hline $\mathbf{1}$ & $35(1)$ & $8(-1)$ & $1.5(-1)$ & 118.0 \\
$\mathbf{2}$ & $30(0)$ & $9(0)$ & $1.5(-1)$ & 150.6 \\
$\mathbf{3}$ & $20(-1.68)$ & $9(0)$ & $2.0(0)$ & 102.0 \\
$\mathbf{4}$ & $25(-1)$ & $8(-1)$ & $2.5(1)$ & 146.0 \\
$\mathbf{5}$ & $40(+1.68)$ & $9(0)$ & $2.0(0)$ & 80.0 \\
$\mathbf{6}$ & $30(0)$ & $9(0)$ & $2.0(0)$ & 171.0 \\
$\mathbf{7}$ & $35(1)$ & $10(1)$ & $1.5(-1)$ & 114.0 \\
$\mathbf{8}$ & $25(-1)$ & $10(1)$ & $2.5(1)$ & 111.4 \\
$\mathbf{9}$ & $25(-1)$ & $8(-1)$ & $1.5(-1)$ & 100.0 \\
$\mathbf{1 0}$ & $35(-1)$ & $10(1)$ & $2.5(1)$ & 119.2 \\
$\mathbf{1 1}$ & $30(0)$ & $9(0)$ & $3.0(+1.68)$ & 164.0 \\
$\mathbf{1 2}$ & $35(1)$ & $8(-1)$ & $2.5(1)$ & 114.0 \\
$\mathbf{1 3}$ & $30(0)$ & $6(-1.68)$ & $2.0(0)$ & 140.0 \\
$\mathbf{1 4}$ & $30(0)$ & $11(+1.68)$ & $2.0(0)$ & 135.0 \\
$\mathbf{1 5}$ & $25(-1)$ & $10(1)$ & $1.5(-1)$ & 100.6 \\
$\mathbf{1 6}$ & $30(0)$ & $9(0)$ & $1.0(-1.68)$ & 99.0 \\
$\mathbf{1 7}$ & $30(0)$ & $9(0)$ & $2.0(0)$ & 171.8 \\
\hline
\end{tabular}

Notes: $x$ : temperature $\left({ }^{\circ} \mathrm{C}\right) ; y$ : time (days); $z$ : initial moisture $\left(\mathrm{mL} \mathrm{g}^{-1}\right)$. Initial moisture of the culture media expressed as wet basis moisture content corresponded to: $46.9 \%\left(1 \mathrm{~mL} \mathrm{~g}^{-1}\right), 55.8 \%\left(1.5 \mathrm{~mL} \mathrm{~g}^{-1}\right), 63.5 \%$ $\left(2.0 \mathrm{~mL} \mathrm{~g}^{-1}\right), 68.6 \%\left(2.5 \mathrm{~mL} \mathrm{~g}^{-1}\right)$ and $73.0 \%\left(3.0 \mathrm{~mL} \mathrm{~g}^{-1}\right)$; ${ }^{a}$ Response values for each run were the means of triplicate experiments, and each enzymatic assay was carried out in duplicate. 
Table 3. Experimental conditions and results of the statistical experimental design for $\beta$-xylosidase production by $C$. graminicola.

\begin{tabular}{ccccc}
\hline \multirow{2}{*}{ Run } & \multicolumn{4}{c}{ Real(Coded) values } \\
\cline { 2 - 5 } & $\boldsymbol{w}$ & $\boldsymbol{y}$ & $\boldsymbol{z}$ & $\boldsymbol{\beta}$-xylosidase ${ }^{\mathbf{a}}\left(\mathbf{U ~ g}^{\mathbf{- 1}} \mathbf{)}\right.$ \\
\hline $\mathbf{1}$ & $1(-1)$ & $7(-1)$ & $1.5(-1)$ & 93.8 \\
$\mathbf{2}$ & $5(1)$ & $7(-1)$ & $1.5(-1)$ & 85.6 \\
$\mathbf{3}$ & $1(-1)$ & $7(-1)$ & $1.5(-1)$ & 99.6 \\
$\mathbf{4}$ & $5(1)$ & $7(-1)$ & $1.5(-1)$ & 104.2 \\
$\mathbf{5}$ & $1(-1)$ & $9(1)$ & $2.5(1)$ & 76.8 \\
$\mathbf{6}$ & $5(1)$ & $9(1)$ & $1.5(-1)$ & 72.6 \\
$\mathbf{7}$ & $1(-1)$ & $9(1)$ & $2.5(1)$ & 60.6 \\
$\mathbf{8}$ & $5(1)$ & $9(1)$ & $2.5(1)$ & 85.4 \\
$\mathbf{9}$ & $3(0)$ & $6(-1.68)$ & $2.0(0)$ & 56.0 \\
$\mathbf{1 0}$ & $3(0)$ & $11(+1.68)$ & $2.0(0)$ & 58.6 \\
$\mathbf{1 1}$ & $3(0)$ & $8(0)$ & $1.0(-1.68)$ & 59.6 \\
$\mathbf{1 2}$ & $3(0)$ & $8(0)$ & $3.0(+1.68)$ & 86.0 \\
$\mathbf{1 3}$ & $0.5(-1.68)$ & $8(0)$ & $2.0(0)$ & 40.2 \\
$\mathbf{1 4}$ & $7(+1.68)$ & $8(0)$ & $2.0(0)$ & 117.4 \\
$\mathbf{1 5}$ & $3(0)$ & $8(0)$ & $2.0(0)$ & 126.0 \\
$\mathbf{1 6}$ & $3(0)$ & $8(0)$ & $2.0(0)$ & 123.0 \\
$\mathbf{1 7}$ & $3(0)$ & $8(0)$ & $2.0(0)$ & 124.6 \\
\hline
\end{tabular}

Notes: $w$ : peanut hulls $(\%, w / w) ; y$ : time (days); $z$ : initial moisture $\left(\mathrm{mL} \mathrm{g}^{-1}\right)$. Initial moisture of the culture media expressed as wet basis moisture content corresponded to: $46.9 \%\left(1 \mathrm{~mL} \mathrm{~g}^{-1}\right), 55.8 \%\left(1.5 \mathrm{~mL} \mathrm{~g}^{-1}\right)$, $63.5 \%\left(2.0 \mathrm{~mL} \mathrm{~g}^{-1}\right), 68.6 \%\left(2.5 \mathrm{~mL} \mathrm{~g}^{-1}\right)$ and $73.0 \%\left(3.0 \mathrm{~mL} \mathrm{~g}^{-1}\right) .{ }^{a}$ Response values for each run were the means of triplicate experiments, and each enzymatic assay was carried out in duplicate.

Table 4. Experimental conditions and results of the statistical experimental design for xylanase production by $C$. graminicola.

\begin{tabular}{ccccccc}
\hline \multirow{2}{*}{ Run } & \multicolumn{5}{c}{ Real(Coded) Values } \\
\cline { 2 - 7 } & $\boldsymbol{x}$ & $\boldsymbol{y}$ & $\boldsymbol{z}$ & $\boldsymbol{k}$ & $\boldsymbol{s}$ & Xylanase $\left(\mathbf{U ~ g}^{-\mathbf{1}} \mathbf{)}\right.$ \\
\hline $\mathbf{1}$ & $25(-1)$ & $6(-1)$ & $1.5(-1)$ & $0.5(-1)$ & $0.7(1)$ & 110.6 \\
$\mathbf{2}$ & $25(-1)$ & $6(-1)$ & $1.5(-1)$ & $1.5(1)$ & $0.3(-1)$ & 70.9 \\
$\mathbf{3}$ & $25(-1)$ & $6(-1)$ & $2.5(1)$ & $0.5(-1)$ & $0.3(-1)$ & 166.3 \\
$\mathbf{4}$ & $25(-1)$ & $6(-1)$ & $2.5(1)$ & $1.5(1)$ & $0.7(1)$ & 140.4 \\
$\mathbf{5}$ & $25(-1)$ & $10(1)$ & $1.5(-1)$ & $0.5(-1)$ & $0.3(-1)$ & 161.0 \\
$\mathbf{6}$ & $25(-1)$ & $10(1)$ & $1.5(-1)$ & $1.5(1)$ & $0.7(1)$ & 128.9 \\
$\mathbf{7}$ & $25(-1)$ & $10(1)$ & $2.5(1)$ & $0.5(-1)$ & $0.7(1)$ & 146.8 \\
$\mathbf{8}$ & $35(1)$ & $10(1)$ & $2.5(1)$ & $1.5(1)$ & $0.3(-1)$ & 190.5 \\
$\mathbf{9}$ & $35(1)$ & $6(-1)$ & $1.5(-1)$ & $0.5(-1)$ & $0.3(-1)$ & 39.1 \\
$\mathbf{1 0}$ & $35(1)$ & $6(-1)$ & $1.5(-1)$ & $1.5(1)$ & $0.7(1)$ & 43.2 \\
$\mathbf{1 1}$ & $35(1)$ & $6(-1)$ & $2.5(1)$ & $0.5(-1)$ & $0.7(1)$ & 146.8 \\
$\mathbf{1 2}$ & $35(1)$ & $6(-1)$ & $2.5(1)$ & $1.5(1)$ & $0.3(-1)$ & 156.9 \\
$\mathbf{1 3}$ & $35(1)$ & $10(1)$ & $1.5(-1)$ & $0.5(-1)$ & $0.7(1)$ & 16.4 \\
$\mathbf{1 4}$ & $35(1)$ & $10(1)$ & $2.5(-1)$ & $0.5(-1)$ & $0.3(-1)$ & 22.8 \\
$\mathbf{1 5}$ & $35(1)$ & $10(1)$ & $2.5(1)$ & $0.5(-1)$ & $0.3(-1)$ & 197.9 \\
$\mathbf{1 6}$ & $35(1)$ & $10(1)$ & $2.5(1)$ & $1.5(1)$ & $0.7(1)$ & 122.3 \\
\hline
\end{tabular}


Table 4. Cont.

\begin{tabular}{ccccccc}
\hline \multirow{2}{*}{ Run } & \multicolumn{5}{c}{ Real(Coded) values } \\
\cline { 2 - 7 } & $\boldsymbol{x}$ & $\boldsymbol{y}$ & $\boldsymbol{z}$ & $\boldsymbol{k}$ & $\boldsymbol{s}$ & Xylanase $\left(\mathbf{U ~ g}^{-\mathbf{1}} \mathbf{)}\right.$ \\
\hline $\mathbf{1 7}$ & $20(-2)$ & $8(0)$ & $2.0(0)$ & $0(1.0)$ & $0.5(0)$ & 32.3 \\
$\mathbf{1 8}$ & $40(2)$ & $8(0)$ & $2.0(0)$ & $1.0(0)$ & $0.5(0)$ & 0.6 \\
$\mathbf{1 9}$ & $30(0)$ & $4(-2)$ & $2.0(0)$ & $1.0(0)$ & $0.5(0)$ & 25.2 \\
$\mathbf{2 0}$ & $30(0)$ & $12(2)$ & $2.0(0)$ & $1.0(0)$ & $0.5(0)$ & 337.1 \\
$\mathbf{2 1}$ & $30(0)$ & $8(0)$ & $1.0(-2)$ & $1.0(0)$ & $0.5(0)$ & 75.4 \\
$\mathbf{2 2}$ & $30(0)$ & $8(0)$ & $3.0(2)$ & $1.0(0)$ & $0.5(0)$ & 290.2 \\
$\mathbf{2 3}$ & $30(0)$ & $8(0)$ & $2.0(0)$ & $0.0(-2)$ & $0.5(0)$ & 370.5 \\
$\mathbf{2 4}$ & $30(0)$ & $8(0)$ & $2.0(0)$ & $2.0(2)$ & $0.5(0)$ & 373.5 \\
$\mathbf{2 5}$ & $30(0)$ & $8(0)$ & $2.0(0)$ & $1.0(0)$ & $0.1(-2)$ & 375.8 \\
$\mathbf{2 6}$ & $30(0)$ & $8(0)$ & $2.0(0)$ & $1.0(0)$ & $0.9(2)$ & 299.0 \\
$\mathbf{2 7}$ & $30(0)$ & $8(0)$ & $2.0(0)$ & $1.0(0)$ & $0.5(0)$ & 352.8 \\
$\mathbf{2 8}$ & $30(0)$ & $8(0)$ & $2.0(0)$ & $1.0(0)$ & $0.5(0)$ & 337.3 \\
$\mathbf{2 9}$ & $30(0)$ & $8(0)$ & $2.0(0)$ & $1.0(0)$ & $0.5(0)$ & 364.7 \\
$\mathbf{3 0}$ & $30(0)$ & $8(0)$ & $2.0(0)$ & $1.0(0)$ & $0.5(0)$ & 355.7 \\
$\mathbf{3 1}$ & $30(0)$ & $8(0)$ & $2.0(0)$ & $1.0(0)$ & $0.5(0)$ & 349.9 \\
$\mathbf{3 2}$ & $30(0)$ & $8(0)$ & $2.0(0)$ & $1.0(0)$ & $0.5(0)$ & 361.1 \\
\hline
\end{tabular}

Notes: $x$ : temperature $\left({ }^{\circ} \mathrm{C}\right) ; y$ : time (days); $z$ : initial moisture $\left(\mathrm{mL} \mathrm{g}^{-1}\right) ; k$ : milled corncob $(\%, w / w)$; $s$ : ammonium sulfate concentration $(\%, w / w)$. Initial moisture of the culture media expressed as wet basis moisture content corresponded to: $46.9 \%\left(1 \mathrm{~mL} \mathrm{~g}^{-1}\right), 55.8 \%\left(1.5 \mathrm{~mL} \mathrm{~g}^{-1}\right), 63.5 \%\left(2.0 \mathrm{~mL} \mathrm{~g}^{-1}\right), 68.6 \%$ $\left(2.5 \mathrm{~mL} \mathrm{~g} \mathrm{~g}^{-1}\right)$ and $73.0 \%\left(3.0 \mathrm{~mL} \mathrm{~g}^{-1}\right) .{ }^{a}$ Response values for each run were the means of triplicate experiments, and each enzymatic assay was carried out in duplicate.

Preliminary analyses by OFAT revealed that the presence of SCT $(0.5 \%$ to $10 \%, w / w)$ in the culture medium enhanced the production of $\beta$-glucosidase by about $60 \%$, compared to that obtained in wheat bran and water only (not shown). However, similar production was obtained for all SCT concentrations tested in this range. In agreement, when the production of $\beta$-glucosidase was optimized using RSM the concentration of SCT and its interactions with the other independent variables tested (temperature, culture time and initial moisture) has not significantly influenced the production (not shown). Thus, the concentration of SCT in the culture medium was fixed at $1 \%$ for further experiments. Similarly, the temperature and its interactions with the other independent variables tested have not significantly influenced the production of $\beta$-xylosidase (not shown), and the production of this enzyme was optimized with respect to culture time, initial moisture and peanut hulls concentration only.

The analyses of variance (ANOVA) for the response surface quadratic models for the production of each enzyme are summarized in Table 5. The coefficients of the full model were analyzed for their significance and the non-significant ones were eliminated from the model. According to the $F$ test, the three models were predictive, since the calculated $F$ values were greater than the listed $F$ values. The low $P$-values also indicate the significance of the models. Further, $P$-values greater than 0.05 indicated that the lack of fit for the models was non-significant. The $\mathrm{R}^{2}$ coefficients of 0.99 for $\beta$-glucosidase, 0.90 for $\beta$-xylosidase and 0.88 for xylanase production confirm the goodness of the three models, indicating that $99 \%, 90 \%$ and $88 \%$, respectively, of the responses variability could be explained by them. 
Table 5. Analysis of variance (ANOVA) for the second order polynomial models, and coefficient values for $\beta$-glucosidase, $\beta$-xylosidase and xylanase production by $C$. graminicola.

\begin{tabular}{|c|c|c|c|c|c|c|c|c|c|c|c|c|c|c|c|}
\hline \multirow{2}{*}{ Source } & \multicolumn{5}{|c|}{$\beta$-glucosidase } & \multicolumn{5}{|c|}{$\beta$-xylosidase } & \multicolumn{5}{|c|}{ Xylanase } \\
\hline & df & SS & MS & $F$ & $p$ & df & SS & MS & $F$ & $p$ & df & SS & MS & $F$ & $p$ \\
\hline $\mathbf{M}$ & 9 & $14,792.38$ & $1,578.15$ & 7.08 & 0.0039 & 9 & $8,927.015$ & 991.89 & 6.17 & 0.0191 & 20 & $402,029.4$ & $20,101.47$ & 3.40 & 0.0402 \\
\hline $\mathbf{R}$ & 8 & $1,452.74$ & 165.89 & & & 6 & 964.563 & 160.76 & - & - & 8 & $47,279.11$ & $5,909.89$ & - & - \\
\hline $\mathbf{L F}$ & 5 & $1,093.82$ & 179.63 & 1.94 & 0.0643 & 6 & $1,441.22$ & 240.204 & 99.258 & 0.0766 & 7 & $53,966.3$ & $3,597.8$ & 19.12 & 0.0507 \\
\hline PE & 3 & 3.17 & 10.3 & - & - & 1 & 2.42 & 0.5 & - & - & 2 & 376.3 & 188.2 & - & - \\
\hline \multicolumn{3}{|c|}{ Effects } & Coefficient & \multicolumn{2}{|c|}{$p$-value } & \multicolumn{2}{|r|}{ Effects } & Coefficient & \multicolumn{2}{|c|}{$p$-value } & \multicolumn{2}{|r|}{ Effects } & Coefficient & \multicolumn{2}{|c|}{$p$-value } \\
\hline \multicolumn{3}{|c|}{ Intercept } & 182.19 & \multicolumn{2}{|c|}{$0.0009^{c}$} & \multicolumn{2}{|c|}{ Intercept } & -1732.78 & \multicolumn{2}{|c|}{$0.0146^{\mathrm{a}}$} & \multicolumn{2}{|r|}{ Intercept } & 373.94 & \multicolumn{2}{|c|}{$0.0004^{\mathrm{c}}$} \\
\hline \multicolumn{3}{|c|}{ X } & -7.39 & \multicolumn{2}{|c|}{0.1985} & & $w$ & -5.51 & \multicolumn{2}{|c|}{0.2404} & & $x$ & -36.80 & \multicolumn{2}{|c|}{$0.0223^{\mathrm{a}}$} \\
\hline \multicolumn{3}{|c|}{$x^{2}$} & -9.45 & \multicolumn{2}{|c|}{$0.0198^{\mathrm{a}}$} & & $w^{2}$ & -3.56 & \multicolumn{2}{|c|}{$0.0202^{\mathrm{a}}$} & & $x^{2}$ & -195.67 & \multicolumn{2}{|c|}{$0.0008^{c}$} \\
\hline \multicolumn{3}{|c|}{$Y$} & 11.41 & \multicolumn{2}{|c|}{0.1429} & & $y$ & 376.92 & \multicolumn{2}{|c|}{$0.0144^{\mathrm{a}}$} & & $y$ & 61.96 & \multicolumn{2}{|c|}{$0.0080^{\mathrm{a}}$} \\
\hline \multicolumn{3}{|c|}{$y^{2}$} & -66.88 & \multicolumn{2}{|c|}{$0.0009^{\mathrm{a}}$} & & $y^{2}$ & -21.76 & \multicolumn{2}{|c|}{$0.0015^{b}$} & & $y^{2}$ & -113.16 & \multicolumn{2}{|c|}{$0.0023^{b}$} \\
\hline & $Z$ & & 17.47 & & 0667 & & $z$ & 359.70 & 0.0 & $85^{\mathrm{a}}$ & & $z$ & 91.43 & & $037^{\mathrm{b}}$ \\
\hline & $z^{2}$ & & -32.69 & & $087^{\mathrm{a}}$ & & $z^{2}$ & -48.12 & 0.0 & $96^{\mathrm{a}}$ & & $z^{2}$ & -112.32 & & $024^{b}$ \\
\hline & - & & - & & - & & $w z$ & 5.14 & 0.0 & $39^{a}$ & & $k$ & -3.65 & & 5807 \\
\hline & - & & - & & - & & $y z$ & 4.00 & 0.0 & $16^{\mathrm{a}}$ & & $k^{2}$ & -26.04 & & $423^{a}$ \\
\hline & - & & - & & - & & & & & & & $s$ & -24.45 & & $486^{\mathrm{a}}$ \\
\hline & & & & & & & & & & & & $s^{2}$ & -35.44 & & $235^{\mathrm{a}}$ \\
\hline & - & & - & & - & & - & - & 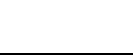 & & & $x z$ & 40.33 & & $277^{\mathrm{a}}$ \\
\hline
\end{tabular}

Notes: $\beta$-glucosidase: $\mathrm{R}^{2}=0.99 ; F$ listed $5 \%=3.35 ; \beta$-xylosidase: $\mathrm{R}^{2}=0.90 ; F$ listed $5 \%=3.22 ;$ Xylanase: $\mathrm{R}^{2}=0.88 ; F$ listed $5 \%=2.64, \mathrm{M}=\mathrm{Model} ; \mathrm{R}=$ residual; $\mathrm{LF}=$ Lack of fit; $\mathrm{PE}=$ Pure error; df: degrees of freedom; SS: sum of squares; MS: mean square. $x$ : temperature $\left({ }^{\circ} \mathrm{C}\right) ; y$ : time (days); $z$ : initial moisture (mL $\left.\mathrm{g}^{-1}\right) ; w$ : peanut hulls concentration $(\%, w / w) ; k$ : milled corncob $(\%, w / w) ; s$ : ammonium sulfate concentration $(\%, w / w) .{ }^{\mathrm{a}} p \leq 0.05 ;{ }^{\mathrm{b}} p \leq 0.005 ;{ }^{\mathrm{c}} p \leq 0.001$ 
The regression coefficients obtained for $\beta$-glucosidase, $\beta$-xylosidase and xylanase production are listed in Table 5. The analysis of the $P$-values showed that the quadratic terms of all independent variables tested had significant effects on $\beta$-glucosidase production, but not their linear terms nor the interactions between them. The quadratic effects of culture time and initial moisture were the most important factors affecting $\beta$-glucosidase production.

Significant effects on $\beta$-xylosidase production were exerted by culture time and initial moisture, the interaction between them, and the interaction between peanut hulls concentration and initial moisture. The quadratic terms of all three independent variables also had significant effects. The linear effects of culture time and initial moisture were the most critical variables that affected the production of $\beta$-xylosidase.

Analysis of the $P$-values for the regression coefficients obtained for xylanase production revealed that temperature, culture time, initial moisture and $\left(\mathrm{NH}_{4}\right)_{2} \mathrm{SO}_{4}$ concentration, and their quadratic terms, significantly affected the enzyme production. The quadratic term of milled corncob concentration and the interaction between temperature and initial moisture also had significant effects. The most important factors that affected xylanase production were the quadratic terms of temperature, culture time and initial moisture.

Among the factors that influence the enzymatic production under SSF, water content is well recognized as one of the most critical. The ideal moisture varies with the organism, the operational conditions and the solid substrate, affecting both the microbial growth and the production and secretion of enzymes. At low moisture content, lower substrate swelling occurs, reducing the superficial area. Moreover, the solubility and diffusion of the nutrients are reduced, as well as the stability of the extracellular enzymes, possibly impairing the growth of the microorganism. In contrast, moisture levels that are too high may cause aggregation of substrate particles, reducing the porosity and thus limiting oxygen availability, also hindering microbial growth and lowering enzyme production [28,33,34].

Tridimensional response surface curves graphically represent regression equations, demonstrating the relationships between the response and experimental levels of each variable and allowing a better understanding of the interactions between the significant independent variables. Moreover, they provide working ranges for each variable, depicting the robustness of a process, i.e., its capability to bring the expected results in the presence of deviations from the optimal conditions or unexpected adverse factors. The 3D response curves for the most important factors that affect the production of $\beta$-glucosidase and $\beta$-xylosidase are shown in Figure 1, while Figure 2 brings those for the factors that influence xylanase production.

Statistical analysis showed that maximum $\beta$-glucosidase production could be achieved after 7.07 days at $28.13{ }^{\circ} \mathrm{C}$, with initial moisture of $2.38 \mathrm{~mL} \mathrm{~g}^{-1}$, using wheat bran as carbon source and $1 \%(w / w)$ sugarcane trash as supplementary carbon source. Maximum predicted value was $156.63 \mathrm{U} \mathrm{g} \mathrm{g}^{-1}, 1.4$-fold higher than observed before optimization. The mean value of the experimental validation of the optimized conditions $\left(159.3 \pm 12.7 \mathrm{U} \mathrm{g}^{-1}\right)$ was in excellent correlation with the predicted value, confirming the validity of the model. Interestingly, the production of $\beta$-glucosidase under optimal temperature, initial moisture and culture time decreased about 50\% in the absence of SCT, but near maximal levels were obtained with SCT concentrations ranging from $1 \%$ to $10 \%$ (w/w) (not shown). Considering that SCT does not support the growth of $C$. graminicola, it is possible that when grown in wheat bran, the fungus partially degrades SCT, liberating little amounts of some compounds that stimulate enzyme production. 
Figure 1. Response surface plots showing the interactive effects of initial moisture and culture time on $\beta$-glucosidase (a) and $\beta$-xylosidase (b) production.

a

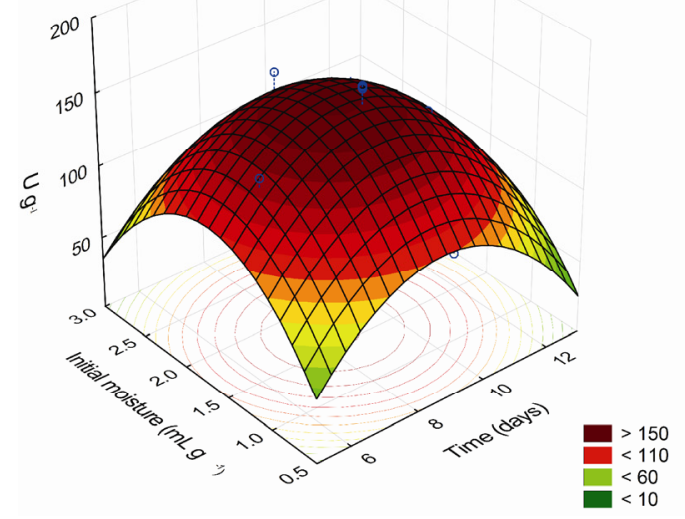

b

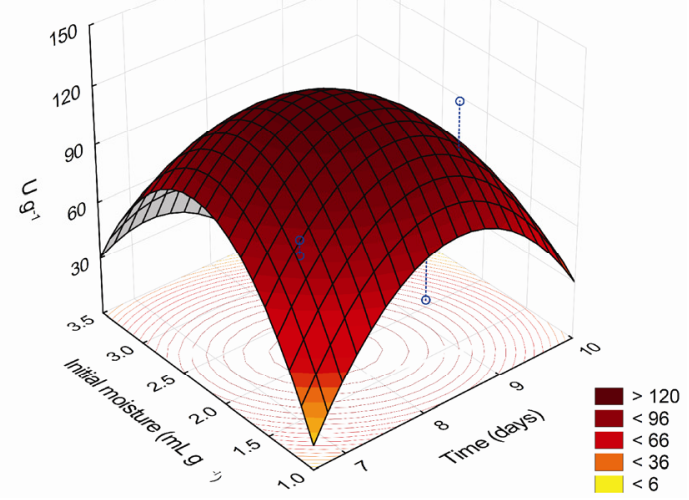

Figure 2. Response surface plots showing the interactive effects of initial moisture and temperature (a) and culture time and temperature (b) on xylanase production.

a

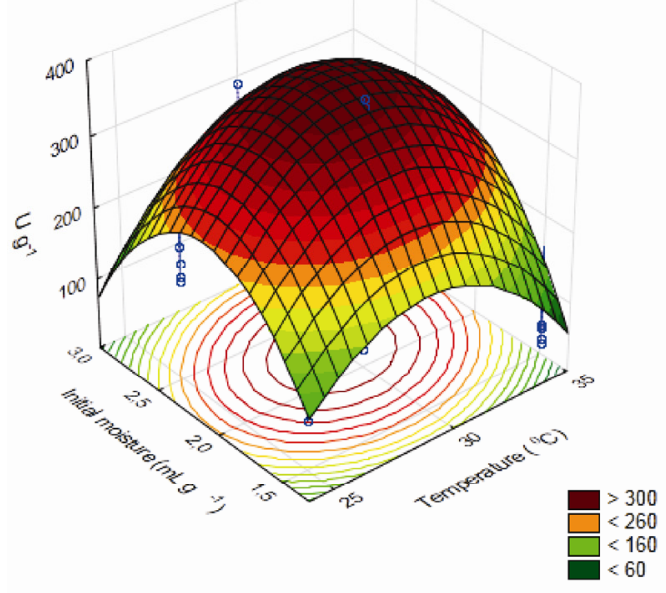

b

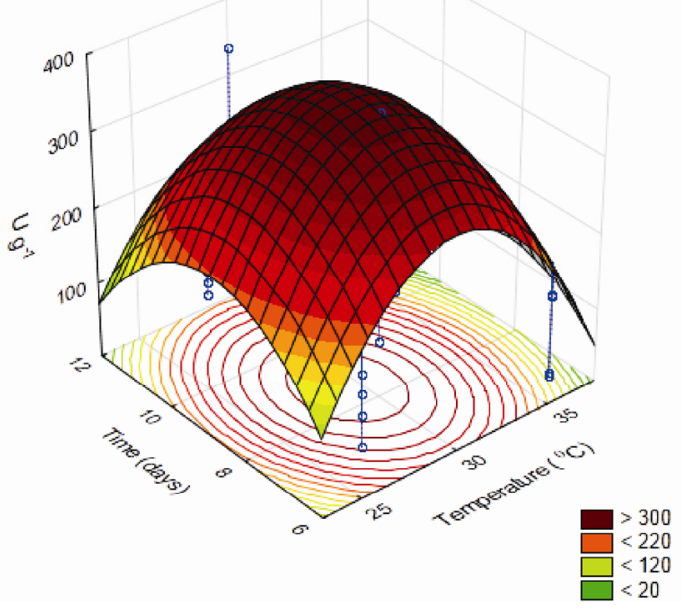

For $\beta$-xylosidase production, the maximum point predicted was 7.71 days, peanut hulls concentration of $4.66 \%(w / w)$ and initial moisture of $2.1 \mathrm{~mL} \mathrm{~g}^{-1}$, at $25{ }^{\circ} \mathrm{C}$, using wheat bran as carbon source. Maximum predicted production was $125.88 \mathrm{U} \mathrm{g}^{-1}$, about 2.2-fold higher than that obtained initially. The mean value of the experimental validation was $128.1 \pm 6.4 \mathrm{U} \mathrm{g}^{-1}$, in good agreement with the predicted value, proving the model's adequacy.

According to the model, maximum xylanase production occurred at $29.7{ }^{\circ} \mathrm{C}, 8.66$ days, initial moisture of $2.21 \mathrm{~mL} \mathrm{~g}^{-1}$, milled corncob concentration of $0.87 \%(w / w)$ and $\left(\mathrm{NH}_{4}\right)_{2} \mathrm{SO}_{4}$ concentration of $0.378 \%(w / w)$, using wheat bran as carbon source. The maximal predicted value, $396.65 \mathrm{U} \mathrm{g}^{-1}$, was 2.1-fold higher than initially estimated, and showed good correlation with the result of the experimental validation $\left(378.1 \pm 23.3 \mathrm{U} \mathrm{g}^{-1}\right)$, establishing the model's validity.

The optimal production levels of $\beta$-glucosidase by $C$. graminicola were higher than most reported in the literature for SSF processes, but values of the same magnitude were found for Aspergillus fumigatus [35] and Trichoderma koningi F244 [36] cultured in wheat bran moistened with 
mineral salt medium or supplemented with ammonium sulfate, respectively. Similar levels were also obtained for Thermoascus aurantiacus grown in wheat straw [37] and Aspergillus terreus M11 in corn stover [38], both supplemented with mineral solutions. Few fungi are good producers of $\beta$-xylosidases under SSF, but the production levels of the mutant strain Aspergillus niger KK2 in rice straw supplemented with salts, yeast extract and corn steep liquor were similar to those found for C. graminicola [26]. Higher production levels were reported for a Brazilian strain of Aspergillus tamarii cultured in wheat bran supplemented with Vogel salts [39] and for the mutant Humicola lanuginosa M7D cultured in corncob supplemented with Vogel salts and corn steep liquor [40]. Similar levels of xylanase, compared to $C$. graminicola, were produced by $A$. niger in wheat bran supplemented with mineral salts [36]. However, 6-fold higher levels of xylanase were produced by some strains of $A$. niger and $T$. reesei [11] in wheat bran supplemented with Mandel Weber medium [41].

Due to the high enzyme loads required for an efficient hydrolysis of lignocellulosic materials, it is estimated that enzyme costs contribute $23 \%-40 \%$ to cellulosic ethanol production cost, directly impacting the economic viability of the process [11,42]. The carbon source is one of the major factors affecting enzyme production costs [38], and thus, there is a rising interest in fungi that produce cellulases and hemicellulases with good yields in inexpensive carbon sources [11,21]. In this context, our results characterize $C$. graminicola as a very promising microorganism for industrial purposes, since few fungal strains produce similar or higher levels of $\beta$-glucosidase, $\beta$-xylosidase and xylanase under SSF $[26,35,38,40]$. Moreover, this good production was obtained in quite cheap media mostly composed of wheat bran, a low-cost industrial byproduct, without addition of any expensive nutritional supplement. The simultaneous production of significant levels of three enzymes involved in the hydrolysis of lignocellulose may be considered another advantage of this fungus, aimed at the reduction of production costs. However, it is well established that the hydrolysis of different lignocellulosic residues, which are highly heterogeneous, requires enzymatic cocktails of distinct compositions for maximal yields [8,25]. Thus, the use of multi-enzyme crude extracts has the disadvantage of limiting the possibility of varying enzyme proportions, making difficult to optimize a cocktail for a specific lignocellulosic residue. Moreover, the presence of contaminant enzymes may have deleterious effects for specific industrial processes.

\subsection{Effect of Temperature and $\mathrm{pH}$ on $\beta$-Glucosidase, $\beta$-Xylosidase and Xylanase Activities and}

\section{Thermal Stabilities}

The effects of $\mathrm{pH}$ and temperature on the enzymatic activities in the crude extracts from C. graminicola cultured under optimal conditions were evaluated using a CCRD for each enzyme, and RSM analyses. The experimental conditions and results of the experimental designs are summarized in Table 6. Data analyses by multiple regressions led to predicted responses for $\beta$-glucosidase ( $\beta$ glu), $\beta$-xylosidase ( $\beta \mathrm{xyl})$ and xylanase (Xyl) activities as follows:

$$
\begin{gathered}
\beta \text { glu }=-1009.78+225.63 \mathrm{pH}+15.28 \mathrm{~T}-21.11 \mathrm{pH}^{2}-0.11 \mathrm{~T}^{2}-0.26 \mathrm{pH} . \mathrm{T} \\
\beta \mathrm{xyl}=-283.64-63.54 \mathrm{pH}+5.20 \mathrm{~T}-7.36 \mathrm{pH}^{2}-0.04 \mathrm{~T}^{2}+0.11 \mathrm{pH} . \mathrm{T} \\
\mathrm{Xyl}=-675.53+42.79 \mathrm{pH}+18.32 \mathrm{~T}-3.48 \mathrm{pH}^{2}-0.13 \mathrm{~T}^{2}-0.096 \mathrm{pH} . \mathrm{T}
\end{gathered}
$$


Table 6. Experimental conditions and results of the statistical experimental designs for $\beta$-glucosidase, $\beta$-xylosidase and xylanase activities.

\begin{tabular}{|c|c|c|c|c|c|c|c|c|c|}
\hline \multirow{2}{*}{ Run } & \multicolumn{3}{|c|}{$\beta$-glucosidase ${ }^{a}$} & \multicolumn{3}{|c|}{$\beta$-xylosidase ${ }^{a}$} & \multicolumn{3}{|c|}{ Xylanase $^{\mathrm{a}}$} \\
\hline & pH & $\mathbf{T}\left({ }^{\circ} \mathrm{C}\right)$ & $\mathrm{U} \mathrm{mg}^{-1}$ & pH & $\mathbf{T}\left({ }^{\circ} \mathrm{C}\right)$ & $\mathrm{U} \mathrm{mg}^{-1}$ & pH & $\mathbf{T}\left({ }^{\circ} \mathrm{C}\right)$ & $\mathrm{U} \mathrm{mg}^{-1}$ \\
\hline 1 & $4.5(-1)$ & $55(-1)$ & 35.7 & $4.5(-1)$ & $55(-1)$ & 31.5 & $4.5(-1)$ & $60(-1)$ & 40.3 \\
\hline 2 & $6.0(+1.41)$ & $65(0)$ & 27.6 & $6.0(+1.41)$ & $65(0)$ & 21.7 & $4.5(-1)$ & $70(1)$ & 46.2 \\
\hline 3 & $5.5(1)$ & $55(-1)$ & 35.6 & $5.5(1)$ & $55(-1)$ & 27.7 & $6.5(1)$ & $60(-1)$ & 37.6 \\
\hline 4 & $4.0(-1)$ & $75(1)$ & 36.3 & $4.5(-1)$ & $75(1)$ & 24.6 & $6.5(1)$ & $70(1)$ & 41.6 \\
\hline 5 & $5.5(1)$ & $75(1)$ & 30.9 & $5.5(1)$ & $75(1)$ & 23.5 & $4.0(-1.41)$ & $65(0)$ & 43.4 \\
\hline 6 & $5.0(0)$ & $65(0)$ & 51.1 & $5.0(0)$ & $65(0)$ & 32.3 & $7.0(+1.41)$ & $65(0)$ & 37.0 \\
\hline 7 & $5.0(0)$ & $50(-1.41)$ & 27.8 & $5.0(0)$ & $50(-1.41)$ & 24.0 & $5.5(0)$ & $55(-1.41)$ & 48.3 \\
\hline 8 & $5.0(0)$ & $65(0)$ & 51.2 & $5.0(0)$ & $65(0)$ & 31.1 & $5.5(0)$ & $75(+1.41)$ & 48.4 \\
\hline 9 & $4.0(-1.41)$ & $65(0)$ & 32.5 & $4.0(-1.41)$ & $65(0)$ & 28.0 & $5.5(0)$ & $65(0)$ & 48.2 \\
\hline 10 & $5.0(0)$ & $80(+1.41)$ & 24.9 & $5.0(0)$ & $80(+1.41)$ & 20.0 & $5.5(0)$ & $65(0)$ & 48.4 \\
\hline 11 & $5.0(0)$ & $65(0)$ & 50.2 & $5.0(0)$ & $65(0)$ & 31.9 & $5.5(0)$ & $65(0)$ & 48.7 \\
\hline
\end{tabular}

Note: ${ }^{a}$ Response values for each run were the means of four experiments, and each enzymatic assay was carried out in triplicate.

The analyses of variance (ANOVA) for the response surface quadratic models are summarized in Table 7. Based on $F$ test, the models were predictive of the enzymatic activities as a function of $\mathrm{pH}$ and temperature, given the higher values for calculated $F$ values compared to listed ones. The low $p$-values also indicate the models' significance. Further, the $p$-values greater than 0.05 indicated that the lack of fit for the models was non-significant. The $\mathrm{R}^{2}$ coefficients of 0.99 for $\beta$-glucosidase, 0.99 for $\beta$-xylosidase and 0.98 for xylanase activities confirm the goodness of the models.

The regression coefficients (Table 7) showed low $p$-values for all linear and quadratic effects, and also for the interaction between $\mathrm{pH}$ and temperature, indicating their significant effect on enzymatic activities. The $\mathrm{pH}$ effects were higher than the temperature effects for the three activities, and working ranges for near optimal activity may be easily anticipated from the response surface curves for each enzymatic activity (Figure 3). Indeed, this is a clear advantage of using RSM to estimate optimal temperature and $\mathrm{pH}$ for enzymatic activity, providing higher flexibility in the development of different bioprocesses [43].

The statistical analysis showed that optimum $\mathrm{pH}$ and temperature for $\beta$-glucosidase activity were 4.94 and $64.61{ }^{\circ} \mathrm{C}$, and the maximum predicted value was $51.16 \mathrm{U} \mathrm{mg}^{-1}$, very close to that obtained in the experimental validation $\left(51.2 \pm 1.6 \mathrm{U} \mathrm{mg}^{-1}\right)$, confirming the model validity. $\beta$-xylosidase activity was maximal at $\mathrm{pH} 4.77$ and $63.33{ }^{\circ} \mathrm{C}$, with a predicted value of $32.59 \mathrm{U} \mathrm{mg}^{-1}$, in excellent correlation with the value of experimental validation $\left(32.4 \pm 0.8 \mathrm{U} \mathrm{mg}^{-1}\right)$. Further, optimal $\mathrm{pH}$ and temperature for xylanase activity were 5.21 and $66.91{ }^{\circ} \mathrm{C}$ with a predicted value of $49.1 \mathrm{U} \mathrm{mg}^{-1}$, in close agreement with the experimental validation, $49.3 \pm 1.4 \mathrm{U} \mathrm{mg}^{-1}$.

$\mathrm{pH}$ optima determined for $C$. graminicola enzymes are in the range found for most fungal $\beta$-glucosidases [27,44], $\beta$-xylosidases [17] and xylanases [27]. Moreover, their elevated optimal temperatures are highly desirable for industrial applications. 
Table 7. Analysis of variance (ANOVA) for the second order polynomial models, and coefficient values for $\beta$-glucosidase, $\beta$-xylosidase and xylanase activities in C. graminicola crude extract.

\begin{tabular}{|c|c|c|c|c|c|c|c|c|c|c|c|c|c|c|c|}
\hline \multirow{2}{*}{ Source } & \multicolumn{5}{|c|}{$\beta$-glucosidase } & \multicolumn{5}{|c|}{$\beta$-xylosidase } & \multicolumn{5}{|c|}{ Xylanase } \\
\hline & df & SS & MS & $F$ & $p$ & df & SS & MS & $F$ & $p$ & df & SS & MS & $F$ & $p$ \\
\hline $\mathbf{M}$ & 5 & 980.468 & 196.094 & 46.11 & 0.0002 & 5 & 202.638 & 40.528 & 149.06 & 0.0003 & 5 & 187.956 & 37.591 & 9.78 & 0.00462 \\
\hline $\mathbf{R}$ & 5 & 0.212 & 0.0425 & - & - & 5 & 0.135 & 0.0271 & - & - & 7 & 26.906 & 3.844 & - & - \\
\hline $\mathbf{L F}$ & 3 & 0.203 & 0.0678 & 14.6 & 0.0646 & 3 & 0.122 & 0.409 & 6.36 & 0.1388 & 3 & 0.276 & 0.092 & 4.79 & 0.08193 \\
\hline PE & 2 & 0.0093 & 0.0046 & - & - & 2 & 0.013 & 0.0064 & - & - & 4 & 0.076 & 0.019 & - & - \\
\hline Factor & \multicolumn{3}{|c|}{ Coefficient } & \multicolumn{2}{|c|}{$p$-value } & \multicolumn{3}{|c|}{ Coefficient } & \multicolumn{2}{|c|}{$p$-value } & \multicolumn{3}{|c|}{ Coefficient } & \multicolumn{2}{|c|}{$p$-value } \\
\hline Intercept & \multicolumn{3}{|c|}{-1009.78} & \multicolumn{2}{|c|}{0.000010} & \multicolumn{3}{|c|}{-283.64} & \multicolumn{2}{|c|}{0.000230} & \multicolumn{3}{|c|}{-675.53} & \multicolumn{2}{|c|}{0.000000} \\
\hline $\mathrm{pH}$ & \multicolumn{3}{|c|}{225.63} & \multicolumn{2}{|c|}{0.000011} & \multicolumn{3}{|c|}{-63.54} & \multicolumn{2}{|c|}{0.000246} & \multicolumn{3}{|c|}{42.79} & \multicolumn{2}{|c|}{0.000002} \\
\hline $\mathrm{pH}^{2}$ & \multicolumn{3}{|c|}{-21.11} & \multicolumn{2}{|c|}{0.000009} & \multicolumn{3}{|c|}{-7.36} & \multicolumn{2}{|c|}{0.000098} & \multicolumn{3}{|c|}{-3.48} & \multicolumn{2}{|c|}{0.000000} \\
\hline $\mathrm{T}$ & \multicolumn{3}{|c|}{15.28} & \multicolumn{2}{|c|}{0.000010} & \multicolumn{3}{|c|}{5.20} & \multicolumn{2}{|c|}{0.000163} & \multicolumn{3}{|c|}{18.32} & \multicolumn{2}{|c|}{0.000000} \\
\hline $\mathrm{T}^{2}$ & \multicolumn{3}{|c|}{-0.11} & 0.0 & 0006 & & -0.04 & & 0.00 & 0049 & & -0.13 & & & 00000 \\
\hline pH.T & & -0.2 & & 0.0 & 0672 & & 0.11 & & 0.00 & 9356 & & -0.096 & & & 02283 \\
\hline
\end{tabular}

Notes: $\beta$-glucosidase: $\mathrm{R}^{2}=0.99 ; F$ listed $5 \%=5.05 ; \beta$-xylosidase: $\mathrm{R}^{2}=0.99 ; F$ listed $5 \%=5.05 ;$ Xylanase: $\mathrm{R}^{2}=0.98 ; F$ listed $5 \%=3.97 ; \mathrm{M}=\mathrm{Model} ; \mathrm{R}=$ residual; $\mathrm{LF}=$ Lack of fit; $\mathrm{PE}=$ Pure error; df: degrees of freedom; SS: sum of squares; MS: mean square. 
Figure 3. Response surface curves for $\mathrm{pH}$ and temperature effects and thermal stabilities of $\beta$-glucosidase (a), $\beta$-xylosidase (b) and xylanase (c) activities. The fungus was cultured under optimal conditions for the production of each enzyme. For thermal stability studies, aliquots of the crude extracts were incubated at (o) $50^{\circ} \mathrm{C},(\boldsymbol{\square}) 55^{\circ} \mathrm{C},(\Delta) 60^{\circ} \mathrm{C},(\bullet) 65^{\circ} \mathrm{C}$ or $(\square) 70^{\circ} \mathrm{C}$. One hundred percent specific activities corresponded to $48.5 \pm 1.4 \mathrm{U} \mathrm{mg}^{-1}$ for $\beta$-glucosidase, $33.2 \pm 0.8 \mathrm{U} \mathrm{mg}^{-1}$ for $\beta$-xylosidase and $47.0 \pm 1.4 \mathrm{U} \mathrm{mg}^{-1}$ for xylanase. Residual activities were estimated in duplicate aliquots, and the values shown represent averages from triplicate experiments $(n=3)$.
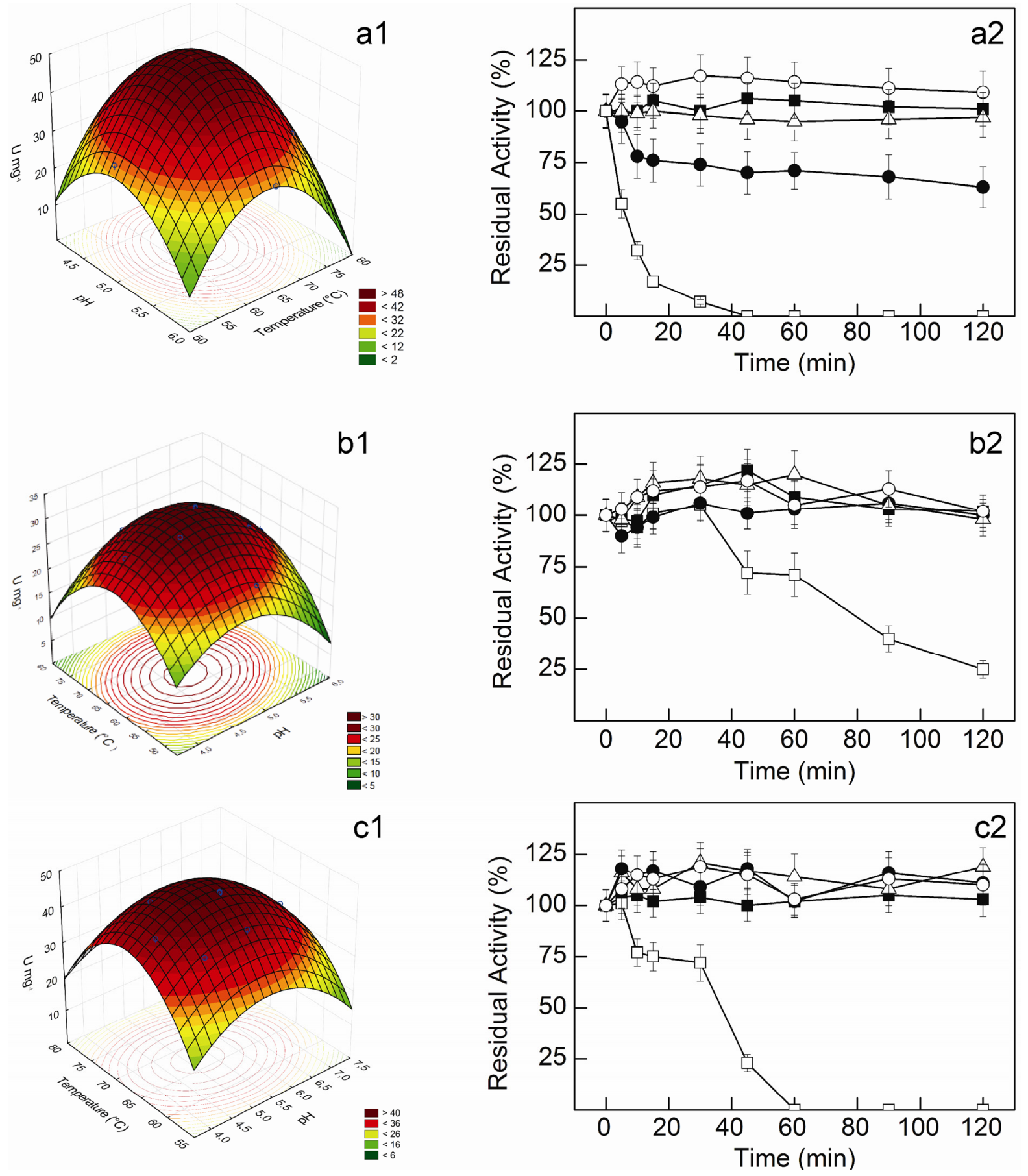
The $\beta$-glucosidase from $C$. graminicola maintained about $100 \%$ of the initial activity up to $72 \mathrm{~h}$ at $50{ }^{\circ} \mathrm{C}$. Moreover, the enzyme was fully stable for $120 \mathrm{~min}$ at $55-60{ }^{\circ} \mathrm{C}$. At $65^{\circ} \mathrm{C}$, a rapid decrease to about $80 \%$ of the initial activity occurred after $10 \mathrm{~min}$, but a residual activity of $63 \%$ remained after 120 min (Figure 3a2). Higher thermal stabilities were observed for the $\beta$-xylosidase and the xylanase. Besides retaining full activity for at least $72 \mathrm{~h}$ at $50{ }^{\circ} \mathrm{C}$, these enzymes remained stable for $120 \mathrm{~min}$ at 55-65 ${ }^{\circ} \mathrm{C}$ (Figure $3 \mathrm{~b} 2, \mathrm{c} 2$ ). At $70{ }^{\circ} \mathrm{C}$, however, half-lives of $6.1,79.0$ and 36.9 min were estimated for $\beta$-glucosidase, $\beta$-xylosidase and xylanase activities, respectively.

The $\beta$-glucosidase from $C$. graminicola was more thermostable than most fungal enzymes studied to date, including those from various thermophilic fungi [44-48]; Few $\beta$-glucosidases with higher thermal stabilities were reported $[31,49,50]$. The $\beta$-xylosidase also showed higher thermal stability than reported for enzymes from different thermophilic species [51-56], but somewhat more thermostable enzymes were produced by a few Aspergillus genera [17] and Humicola lanuginosa [40]. Similarly, C. graminicola xylanase was more thermostable than several enzymes from different thermophiles, with half-lives in the range of 4-115 min at $60{ }^{\circ} \mathrm{C}$ [57-60]. Some highly thermostable xylanases are, however, produced by Thermomyces lanuginosus THKU-49 [61] and Talaromyces thermophilus [62], with half-lives of $336 \mathrm{~min}$ at $70{ }^{\circ} \mathrm{C}$ and $1.0 \mathrm{~h}$ at $100{ }^{\circ} \mathrm{C}$, respectively. The high thermal stability of $C$. graminicola $\beta$-glucosidase, $\beta$-xylosidase and xylanase constitutes another very interesting feature for their employment in biotechnological processes.

\subsection{Synergic Action of C. graminicola Crude Extract and T. reesei Cellulases on Raw Sugarcane} Trash Hydrolysis

Initially, the optima of temperature and $\mathrm{pH}$, and the thermal stability of the cellulases in the crude extract from $T$. reesei were studied. The optimal $\mathrm{pH}$ for cellulase activity was 4.5 to 5.0 , and the optimal temperature was $50-55^{\circ} \mathrm{C}$, with a sharp decrease at $60{ }^{\circ} \mathrm{C}$. About $70 \%$ of $T$. reesei cellulases activity was retained after $72 \mathrm{~h}$ at $50{ }^{\circ} \mathrm{C}$, but at higher temperatures, low residual activities were estimated after $24 \mathrm{~h}$ (not shown). Considering that the $\beta$-glucosidase, $\beta$-xylosidase and xylanase in C. graminicola crude extract showed optimal $\mathrm{pH}$ around 5.0, where they were fully stable at $50{ }^{\circ} \mathrm{C}$ up to $72 \mathrm{~h}$ and presented about $55 \%$ of their maximal activity at $50{ }^{\circ} \mathrm{C}$, the conditions chosen for RSCT hydrolysis were $50{ }^{\circ} \mathrm{C}$ and $\mathrm{pH}$ 5.0.

The crude extracts from $T$. reesei and $C$. graminicola were then characterized for specific activities at $50{ }^{\circ} \mathrm{C}$ and $\mathrm{pH}$ 5.0. Trichoderma reesei extract showed good levels of CMCase $\left(3.7 \pm 0.5 \mathrm{U} \mathrm{mL}^{-1}\right)$, FPA $\left(0.29 \pm 0.04 \mathrm{U} \mathrm{mL}^{-1}\right)$ and avicelase $\left(0.30 \pm 0.05 \mathrm{U} \mathrm{mL}^{-1}\right)$, but low levels of cellobiase $\left(0.002 \mathrm{U} \mathrm{mL}^{-1}\right)$ and undetectable levels of the other activities tested. In contrast, low levels of cellulases were found in the extract from $C$. graminicola $\left(0.28 \pm 0.04 \mathrm{U} \mathrm{mL}^{-1} \mathrm{CMCase} ; 0.08 \pm 0.02 \mathrm{FPU} \mathrm{mL}^{-1} ; 0.044 \pm 0.008 \mathrm{U} \mathrm{mL}^{-1}\right.$ avicelase), which showed high levels of cellobiase $\left(7.6 \pm 0.9 \mathrm{U} \mathrm{mL}^{-1}\right), \beta$-xylosidase $\left(5.0 \pm 0.8 \mathrm{U} \mathrm{mL}^{-1}\right)$ and xylanase $\left(34.6 \pm 4.9 \mathrm{U} \mathrm{mL}^{-1}\right)$ activities, as well as some $\alpha$-L-arabinofuranosidase activity $\left(0.11 \pm 0.02 \mathrm{U} \mathrm{mL}^{-1}\right)$. Similar profiles were obtained for $C$. graminicola crude extracts produced at optimized conditions for $\beta$-glucosidase, $\beta$-xylosidase or xylanase production, despite some variation in the proportions of the main enzymes (not shown).

The time course of RSCT hydrolysis using C. graminicola and T. reesei crude extracts is shown in Figure 4. Treatment with $C$. graminicola extract only resulted in maximal yields of $11.3 \%$ reducing 
sugars and $4.4 \%$ glucose after $72 \mathrm{~h}$. Higher yields were obtained using $T$. reesei extract, attaining $18.3 \%$ reducing sugars and $18.7 \%$ glucose. However, when using a mixture of both extracts, a synergic effect was observed, and yields of $24.6 \%$ reducing sugars and $25.5 \%$ glucose were attained just after $24 \mathrm{~h}$. Moreover, maximal yields reached $37.6 \%$ reducing sugars and $33.1 \%$ glucose, after $48 \mathrm{~h}$. The low yields of glucose obtained using $C$. graminicola crude extract reflect its low levels of cellulases. The inefficient hydrolysis of cellulose results in low production of cellobiose and, consequently, low glucose release by $\beta$-glucosidases, although present at high levels. The higher levels of reducing sugars compared to glucose thus possibly reflect the action of xylanases and $\beta$-xylosidases on RSCT, generating xyloligosaccharides and xylose. In contrast, the reducing sugars obtained using the cellulase-rich crude extract from $T$. reesei must derive from cellulose hydrolysis. Some glucose was also obtained, since this extract presents low levels of $\beta$-glucosidases, but the plateau of reducing sugars observed after $48 \mathrm{~h}$ suggests accumulation of cellobiose, inhibiting endo- and exo-glucanases, as reported by others $[15,25]$. The synergic effect observed when a mixture of the two crude extracts was used may be explained by the presence of good levels of xylanases, $\beta$-xylosidases and $\beta$-glucosidases ( $C$. graminicola extract), as well as cellulases ( $T$ reesei extract), as proposed by other authors $[8,10,13,14]$. The hydrolysis of xylan by the action of xylanases exposes the cellulosic fibers to cellulases, resulting in higher efficiency of cellulose hydrolysis and liberation of good levels of cellobiose. Efficient cellobiose hydrolysis by $\beta$-glucosidases then generates good levels of glucose and releases cellulases from product inhibition. Simultaneously, cellulose degradation increases xylan exposure to xylanases, amplifying the synergic effect. Moreover, the hydrolysis of xylan and xyloligosaccharides to xylose releases the cellulases from inhibition by these compounds [13]. The net result is a faster hydrolysis of RSCT with higher yields of both glucose and reducing sugars. The maximal hydrolysis yield, however, is limited by the high content of lignin in RSCT (20\%-36\%), that hinders an efficient action of the hydrolytic enzymes [3,42,63,64].

Despite its increasing importance as a sustainable feedstock for cellulosic ethanol production, little information is available on SCT, and few authors have studied its enzymatic hydrolysis. Moreover, most studies reported were carried out using SCT submitted to different pre-treatments to increase the accessibility of cellulose and hemicelluloses to the enzymes [3,42,63-65]. Glucose yields of about $80 \%$ to $90 \%$ were attained using SCT pre-treated with dilute acid [3,42], steam [63] or ammonia [64], or submitted to milling [65]. In contrast, to the best of our knowledge, a single study provided some data on RSCT hydrolysis [65], reporting a maximal glucose yield of $23.5 \%$ after $72 \mathrm{~h}$ using a cocktail of commercial enzymes.

The higher efficiency of our cocktail for RSCT hydrolysis, compared to that used by Sant'Ana da Silva et al. [65], may be at least in part attributed to the high content of xylanases and $\beta$-xylosidases, besides $\beta$-glucosidases, in $C$. graminicola crude extract. Similar FPU loads (15 FPU g ${ }^{-1}$ RSCT) were used in both studies. Further, a CMCase load about 1.7-fold lower was employed in this study. In contrast, the cellobiase and xylanase loads were about 3-fold higher, and our cocktail also contained around $225 \mathrm{U} \mathrm{g}^{-1}$ of $\beta$-xylosidase activity, almost absent $\left(1.4 \mathrm{U} \mathrm{g}^{-1}\right)$ from the other cocktail. Thus, our higher glucose yield may be directly related to a higher efficiency of xylan degradation, resulting in an improved action of cellulases. Indeed, the xylan content of SCT is around $23 \%(w / w)[5,64]$, and the composition of $C$. graminicola crude extract seems to be naturally very well suited for the hydrolysis of this particular lignocellulosic residue, with the addition of crude cellulases only. 
Figure 4. Time course of raw sugarcane trash hydrolysis. ( $\square$ ) T. reesei crude extract, enzyme load per gram of substrate 14.5 FPU, 185 U CMCase, $15 \mathrm{U}$ Avicelase and $0.1 \mathrm{U}$ cellobiase; $(\Delta)$ C. graminicola crude extract, enzyme load per gram 3.6 FPU, $12.5 \mathrm{U}$ CMCase, $2.0 \mathrm{U}$ Avicelase, $342 \mathrm{U}$ cellobiase, $225 \mathrm{U} \beta$-xylosidase, $1557 \mathrm{U}$ xylanase and $5.0 \mathrm{U} \alpha$-arabinofuranosidase; $(\bullet)$ mixture of $T$. reesei and $C$. graminicola crude extracts, enzyme load per gram 14.6 FPU, 155 U CMCase, 13.6 U Avicelase, 342 U cellobiase, $225 \mathrm{U} \beta$-xylosidase, $1557 \mathrm{U}$ xylanase and 5.0 $\mathrm{U} \alpha$-arabinofuranosidase. Enzymatic assays were performed on duplicate aliquots, and the values shown represent averages from triplicate experiments $(n=3)$.

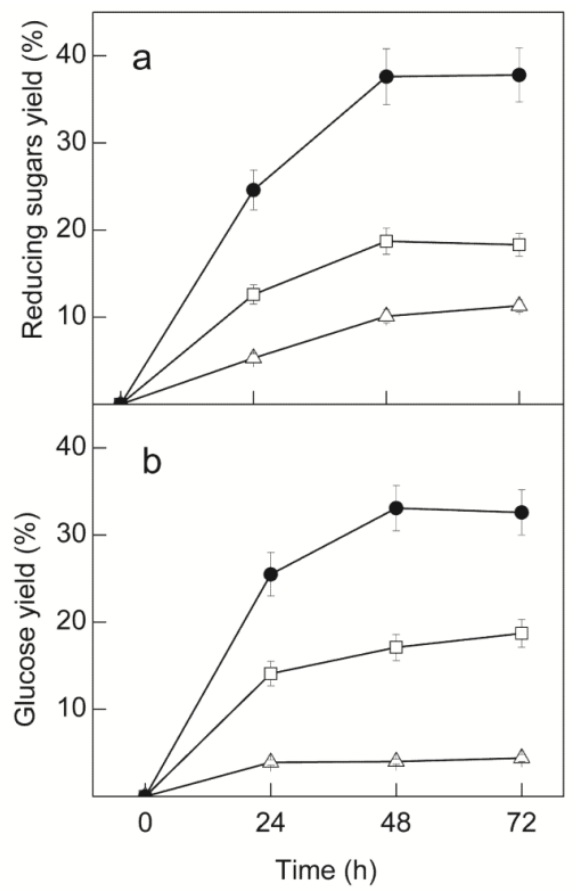

Finally, considering that the conditions for the hydrolysis of RSCT (incubation time, biomass loading, enzyme loading, etc.) using the $C$. graminicola cocktail were not yet optimized, increases in glucose yields are to be expected. Moreover, the addition of some other enzymes to the cocktail, such as ligninases, may increase the hydrolysis efficiency, as well as some mild, low-cost pre-treatment of SCT. Thus, this low-cost cellulolytic-hemicelulolytic enzyme system seems promising for future industrial use. However, its real practical applicability depends on several factors, including the success of scaling up the processes of enzyme production and SCT hydrolysis. Further, the implementation of any industrial process of enzymatic hydrolysis of a lignocellulosic residue for ethanol production depends on a complete techno-economic evaluation of the final production costs [5].

\section{Experimental Section}

\subsection{Organisms and Strains Maintenance}

The Colletotrichum strain was isolated by chance from Amazon rainforest soil, Brazil. Samples from soil were cultured in PDA supplemented with $50 \mu \mathrm{g} \cdot \mathrm{mL}^{-1}$ antibiotics from Fort Dodge (Brazil) which contains a mixture of benzylpenicillin benzathine, benzylpenicillin procaine, diidroestreptomicin 
sulfate, potassium benzylpenicillin and streptomycin sulfate. The cultures were incubated at $25{ }^{\circ} \mathrm{C}$ for 48-72 $\mathrm{h}$ and the initial colonies formed were transferred and maintained in laboratory in PDA slant medium. Colletotrichum graminicola was classified on basis of physiological and morphological characteristics, including the conidiophores morphology, analyzed according to Barnett and Hunter [66] and confirmed by conidia germination analyses [67]. The fungus was maintained on Potato Dextrose Agar (PDA: Oxoid, UK) medium, at $25{ }^{\circ} \mathrm{C}$. Trichoderma reesei QM9414 (ATCC 26921) was maintained at $25{ }^{\circ} \mathrm{C}$ on solid $4 \%$ oatmeal baby food (Quaker) medium.

\subsection{Preliminary Screening for the Best Carbon Sources and Supplementary Nitrogen and Carbon} Sources for the Production of $\beta$-Glucosidase, $\beta$-Xylosidase and Xylanase

Sections $\left(0.25 \mathrm{~cm}^{2}\right)$ of the mycelium of $C$. graminicola grown on PDA medium were taken from 8-day-old cultures and inoculated into sterile solid media prepared in $250 \mathrm{~mL}$ Erlenmeyer flasks, containing $10 \mathrm{~mL}$ of deionized water and $5 \mathrm{~g}$ of different dry carbon sources. Each section contained fungi in all extension and was put onto the culture medium using an inoculation needle, in order to achieve the maximum contact between the mycelium and the medium. The transferences of the mycelial sections were performed in an inoculation chamber, and all the usual aseptic procedures were maintained both during the transferences and the cultures growth. The flasks were incubated for $192 \mathrm{~h}$ under static conditions in a controlled environment incubator (New Brunswick Scientific: Edison, NJ, USA) at $25{ }^{\circ} \mathrm{C}$ and $70 \%$ humidity, monitored by a thermo hygrometer (Minipa: São Paulo State, Brazil). All experiments were conducted in triplicate. The enzymatic assays were carried out in duplicate. After choosing the best carbon source for the production of each enzyme, the effect of supplementation with different nitrogen and carbon sources was investigated under the same culture conditions.

\subsection{Response Surface Methodology for the Optimization of $\beta$-Glucosidase, $\beta$-Xylosidase and} Xylanase Production

After selecting the best carbon source, and supplementary nitrogen and carbon sources for the production of each enzyme, RSM was employed for production optimization.

To optimize the production of $\beta$-glucosidase using wheat bran as the carbon source, the levels of the independent variables (sugarcane trash concentration, temperature, culture time, medium initial moisture) were defined according to a $2^{4}$ full-factorial central composite design (star configuration) with 8 axial and 3 central points (triplicate in the central point only) which resulted in 27 experiments. The experimental ranges of each independent variable tested in RSM experiments were determined preliminarily, using the OFAT methodology, corresponding to a sugarcane trash concentration range of $0.5 \%$ to $10 \%(w / w)$, a temperature range of $20-40{ }^{\circ} \mathrm{C}$, culture time from 7 to 11 days and medium initial moisture from 1.0 to $2.5 \mathrm{~mL}$ deionized $\mathrm{H}_{2} \mathrm{O} \mathrm{g}^{-1}$ dry substrate (wet basis moisture content from $46.9 \%$ to $73 \%, w / w)$. Since SCT concentration and its interactions with the other independent variables tested have not significantly influenced enzyme production, SCT was added to wheat bran at $1 \%(w / w)$ fixed concentration. The levels of the other independent variables (temperature, culture time, medium initial moisture) were then defined according to a $2^{3}$ full-factorial central composite design (star 
configuration) with six axial and two central points (duplicate in the central point only) which resulted in 17 experiments (Table 2).

Similarly, to optimize the production of $\beta$-xylosidase, the levels of the independent variables (concentration of peanut hull, temperature, culture time, medium initial moisture) were defined according to a $2^{4}$ full-factorial central composite design (star configuration) with 8 axial and 3 central points (triplicate in the central point only) which resulted in 27 experiments. The experimental ranges of each independent variable tested were defined preliminarily using the OFAT methodology, corresponding to a peanut hulls concentration range of $0.5 \%$ to $7 \%(w / w)$, a temperature range of $20-40{ }^{\circ} \mathrm{C}$, culture time from 6 to 10 days and medium initial moisture from 0.5 to $3.0 \mathrm{~mL}$ deionized $\mathrm{H}_{2} \mathrm{O}$ per g dry substrate (wet basis moisture content from $31.3 \%$ to $73 \%, w / w$ ). Since temperature and its interactions with the other independent variables tested have not significantly influenced enzyme production, it was fixed at $25{ }^{\circ} \mathrm{C}$. The levels of the other independent variables (concentration of peanut hull, culture time, medium initial moisture) were defined according to a $2^{3}$ full-factorial central composite design (star configuration) with six axial and three central points (triplicate in the central point only) which resulted in 17 experiments (Table 3).

For xylanase production optimization, the levels of the independent variables (temperature, culture time, medium initial moisture, milled corncob concentration and ammonium sulfate concentration) were defined according to a $2^{5-1}$ fractional factorial central composite design (star configuration) with ten axial and six central points (six replicates of the central point only), resulting in 32 experimental runs (Table 4). The experimental ranges of each independent variable tested were defined preliminarily using the OFAT methodology, corresponding to: temperature, $20-40{ }^{\circ} \mathrm{C}$; culture time, $4-12$ days; medium initial moisture, 1.0-3.0 mL deionized $\mathrm{H}_{2} \mathrm{O}$ per g dry substrate (wet basis moisture content from $46.9 \%$ to $73 \%, w / w)$, milled corncob concentration, $0.0 \%-2.0 \%, w / w$; ammonium sulfate concentration, $0.1 \%-0.9 \%(w / w)$. All the experiments were conducted in triplicate and the enzymatic assays were carried out in duplicate. Initial moisture of the culture media was expressed as volume of deionized $\mathrm{H}_{2} \mathrm{O}(\mathrm{mL})$ per $\mathrm{g}$ dry substrate or as wet basis moisture content, experimentally determined and calculated according to the following equation:

$$
M_{w b}=\frac{m_{H_{2} \mathrm{O}}}{m_{\mathrm{H}_{2} \mathrm{O}}+m_{d s}}
$$

where $M_{\mathrm{wb}}(\%)=$ wet-basis moisture content; $m_{\mathrm{H}_{2} \mathrm{O}}=$ mass of moisture $(\mathrm{g})$, and $m_{\mathrm{ds}}=$ mass of dry substrate $(\mathrm{g})$.

\subsection{Enzyme Extraction}

After C. graminicola growth, culture medium was suspended in $30 \mathrm{~mL}$ cold water, gently homogenized with a glass rod in an ice bath, filtered through a nylon sieve and centrifuged at $10,000 \times g$ and $4{ }^{\circ} \mathrm{C}$ for $15 \mathrm{~min}$. The supernatant (crude extract) was maintained at $4{ }^{\circ} \mathrm{C}$ with no appreciable losses of $\beta$-glucosidase, $\beta$-xylosidase and xylanase activities up to 30 days. 


\subsection{Enzymatic Assays}

$\beta$-glucosidase and $\beta$-xylosidase activities were routinely determined using p-nitrophenyl- $\beta$-D-glucopyranoside and p-nitrophenyl- $\beta$-D-xylopyranoside (pNP-glu and pNP-xyl, respectively, Sigma-Aldrich Chem. Co.: St. Louis, MO, USA), as described by Souza et al. [44]. Standard assay conditions were $65{ }^{\circ} \mathrm{C}, 50 \mathrm{mmol} \mathrm{L}^{-1}$ sodium acetate buffer, $\mathrm{pH} 5.0$, and $2.0 \mathrm{mmol} \mathrm{L}^{-1}$ substrate, in a final volume of $0.6 \mathrm{~mL}$. Xylanase activity was routinely assayed in the same conditions using 1\% $(\mathrm{m} / \mathrm{v})$ Birchwood xylan (Sigma-Aldrich Chem. Co.: St. Louis, MO, USA) as substrate, in a final volume of $1.0 \mathrm{~mL}$. The reducing sugars released were quantified using the dinitrosalicylic acid (DNS) method [68].

To characterize the crude extracts from $C$. graminicola and $T$. reesei employed in RSCT hydrolysis, $\beta$-glucosidase, $\beta$-xylosidase and xylanase activities were assayed as above, at $50{ }^{\circ} \mathrm{C}$. $\alpha$-L-Arabinofurosidase activity was assayed in the same conditions using p-nitrophenyl- $\alpha$-L-arabinofuranoside (Sigma-Aldrich Chem. Co.: St. Louis, MO, USA) as substrate, according to the method described by Souza et al. [44]. Hydrolysis of cellobiose $\left(10 \mathrm{mmol} \mathrm{L}^{-1}\right)$ was estimated under the same conditions by quantifying glucose released using the glucose oxidase method [69]. Hydrolytic activities against microcrystalline cellulose (Avicel ${ }^{\circledR}$, Fluka Chemical Co.: Seelze, Germany), carboximethylcellulose (CMC) and filter paper (FPase activity) were assayed in the same conditions using Avicel or CMC at $1 \%(w / v)$ concentration, or a strip $(1 \mathrm{~cm} \times 3 \mathrm{~cm})$ of Whatman No. 1 filter paper, quantifying the reducing sugars released by the DNS method.

Experimental conditions (reaction times, enzymatic units) employed in all activity measurements were adjusted to guarantee the estimation of initial velocities (hydrolysis of no more than 5\% initial substrate, linear response of product formation in respect to reaction time). One enzyme unit (1U) was defined as the amount of enzyme that releases $1 \mu \mathrm{mol}$ of product per min. One filter paper enzyme unit (FPU) was defined as the amount of enzyme that releases $1 \mu \mathrm{mol}$ of product per min using filter paper as substrate.

\subsection{Effect of Temperature and pH on Enzymatic Activities and Thermal Stabilities}

To evaluate the effects of temperature and $\mathrm{pH}$ and their possible interactions on $\beta$-glucosidase activity of $C$. graminicola crude extract the levels of the independent variables were defined according to a $2^{2}$ full-factorial central composite design (star configuration) comprising 11 experimental runs, including 4 axial and 3 central points (triplicate in the central point only). The same design was applied for $\beta$-xylosidase and xylanase activities (Table 6 ). The reactions were carried out using $2 \mathrm{mmol} \mathrm{L}^{-1}$ pNP-glu or pNP-xyl or 1\% xylan as substrates in McIlvaine buffer [70] at different $\mathrm{pH}$ values. All the experiments were conducted in quadruplicate and the enzymatic assays were carried out in triplicate.

The optimum temperature for cellulase activity of $T$. reesei crude extract was determined in the range from 35 to $60{ }^{\circ} \mathrm{C}$ in $50 \mathrm{mmol} \mathrm{L}{ }^{-1}$ sodium acetate buffer, $\mathrm{pH} 5.0$, using $\mathrm{CMC}$, filter paper and avicel as substrates. The optimum $\mathrm{pH}$ for the hydrolysis of each substrate was determined at $50{ }^{\circ} \mathrm{C}$ in McIlvaine buffer [70] at different $\mathrm{pH}$ (3.0 to 8.0).

The thermal stability of $C$. graminicola $\beta$-glucosidase, $\beta$-xylosidase and xylanase was evaluated by incubating the crude extract for different time intervals at temperatures ranging from 50 to $70{ }^{\circ} \mathrm{C}$. After 
cooling in an ice bath for $1 \mathrm{~min}$, the residual activities were determined at $65{ }^{\circ} \mathrm{C}$. The thermal stability of CMCase activity of $T$. reesei crude extract was evaluated as above, at $50{ }^{\circ} \mathrm{C}$, and the residual activity was estimated at $50{ }^{\circ} \mathrm{C}$. The enzymatic activity assays using different substrates were carried out as described in the item 3.5.

\subsection{Determination of Protein}

Protein concentrations were measured according to Read and Northcote [71] using bovine serum albumin as standard.

\subsection{Data Fitting and Statistical Analysis}

RSM was conducted using the software Statistica, version 10.0 (StatSoft, Inc.: Tulsa, OK, USA) for the experimental designs and regression analyses of the data. A statistical analysis of each model was performed to estimate the analysis of variance (ANOVA), the quality of each polynomial model equation was statistically evaluated by the coefficient $R^{2}$, and its statistical significance was checked by an F-test. For all other experiments, data fitting and statistical analyses were carried out using OriginPro 8 SRO software package (OriginLab Corp.: Northampton, MA, USA).

\subsection{Experimental Validation of the Optimized Conditions}

Three cultures for $\beta$-glucosidase, $\beta$-xylosidase and xylanase production, under optimized conditions, were carried out to validate the optimization. Similarly, the optimization of reaction $\mathrm{pH}$ and temperature for the enzymatic activities was validated by performing a triplicate experiment in the optimized conditions.

\subsection{Synergic Action of C. graminicola and T. reesei Crude Extracts on RSCT Hydrolysis}

Colletotrichum graminicola crude extract was obtained from 9-day cultures at $30{ }^{\circ} \mathrm{C}$ in wheat bran containing $0.9 \%(w / w)$ milled corncob and $0.4 \%(w / w)\left(\mathrm{NH}_{4}\right)_{2} \mathrm{SO}_{4}$, with initial moisture of $2.2 \mathrm{~mL} \mathrm{~g}^{-1}$ (optimal conditions for xylanase production), at 70\% humidity. Trichoderma reesei QM9414 was grown for $72 \mathrm{~h}$ at $28{ }^{\circ} \mathrm{C}$ and $130 \mathrm{rpm}$ in 500-mL Erlenmeyer flasks containing $100 \mathrm{~mL}$ of liquid medium composed of $0.03 \%$ urea, $0.14 \%\left(\mathrm{NH}_{4}\right)_{2} \mathrm{SO}_{4}, 0.2 \% \mathrm{KH}_{2} \mathrm{PO}_{4}, 0.03 \% \mathrm{CaCl}_{2} \cdot 2 \mathrm{H}_{2} \mathrm{O}, 0.03 \%$ $\mathrm{MgSO}_{4} \cdot 7 \mathrm{H}_{2} \mathrm{O}, 5.0 \mathrm{mg} \mathrm{mL}^{-1} \mathrm{FeSO}_{4} \cdot 7 \mathrm{H}_{2} \mathrm{O}, 1.6 \mathrm{mg} \mathrm{mL}^{-1} \mathrm{MnSO}_{4}, 1.4 \mathrm{mg} \mathrm{mL}^{-1} \mathrm{ZnSO}_{4} \cdot 7 \mathrm{H}_{2} \mathrm{O}, 2 \mathrm{mg} \mathrm{mL}{ }^{-1}$ $\mathrm{CoCl}_{2}, 0.075 \%$ peptone, $0.2 \%$ Tween-80 and $0.75 \%$ Avicel $^{\circledR}$, with initial pH adjusted for 5.5-6.0. Cellulase-rich $T$. reesei crude extract, obtained by filtration of the culture medium through synthetic sponge, was maintained at $4{ }^{\circ} \mathrm{C}$ for a month without appreciable activity losses.

Before hydrolysis, RSCT (kindly provided by Companhia Albertina Mercantil e Industrial: Sertãozinho, São Paulo State, Brazil) was washed until detection of negligible levels of reducing sugars in washing waters (DNS method). Washed RSCT was dried overnight at $60{ }^{\circ} \mathrm{C}$ and grinded with a domestic blender ( 5 min, maximum speed). Enzymatic hydrolysis was carried out at $50{ }^{\circ} \mathrm{C}$ and $180 \mathrm{rpm}$ in $50 \mathrm{mmol} \mathrm{L}^{-1}$ sodium acetate buffer, $\mathrm{pH} 5.0$, containing $1 \%(w / v) \mathrm{RSCT}$ and $10 \mathrm{mmol} \mathrm{L}^{-1}$ sodium azide in a final volume of $20 \mathrm{~mL}$, in hermetically closed 250-mL Erlenmeyer flasks. Hydrolysis was initiated by addition of an aliquot of $T$. reesei crude extract, an aliquot of 
C. graminicola crude extract or a mixture of both. After desired time intervals, $0.5 \mathrm{~mL}$ aliquots of the reaction medium were withdrawn, centrifuged at $10,000 \times \mathrm{g}$ for $5 \mathrm{~min}$ and the supernatants were analyzed for reducing sugars and glucose.

The yield of RSCT hydrolysis was calculated as a percentage of maximal reducing sugars or glucose released by sulfuric acid hydrolysis, according to the National Renewable Energy Laboratory (NREL) Laboratory Analytical Procedure (LAP) for the quantification of structural carbohydrates [72].

\section{Conclusions}

Colletotrichum graminicola is a significant producer of $\beta$-glucosidase, $\beta$-xylosidase and xylanase under SSF in cheap media, comprising of wheat bran as carbon source and agricultural residues as supplements. All three enzymes are produced simultaneously at good levels, and crude culture extracts may thus be used without further processing to compose efficient cocktails for lignocellulosic material hydrolysis. Indeed, a cocktail composed of C. graminicola crude extract supplemented with $T$. reesei crude cellulases hydrolyzed raw sugarcane trash with a yield of $33.1 \%$ glucose after $48 \mathrm{~h}$, demonstrating strong potential for the hydrolysis of this interesting, cheap feedstock for the production of cellulosic ethanol.

\section{Acknowledgments}

This investigation was supported by research grants from CNPq (Conselho de Desenvolvimento Científico e Tecnológico), FAPESP (Fundação de Amparo à Pesquisa do Estado de São Paulo), CAPES (Coordenação de Aperfeiçoamento de Pessoal de Nível Superior) and INCT (Instituto Nacional de Ciência e Tecnologia)-ADAPTA. ALRLZ received PhD scholarships from CAPES and FAPESP; CS received an undergraduate scholarship from CNPq; LPM and FHMS received PhD scholarships from FAPESP, DCM received a post-doctoral scholarship from CNPq. JAJ and RPMF received research scholarships from $\mathrm{CNPq}$. We thank Nilton Rosa Alves and Mauricio de Oliveira for technical assistance.

\section{References}

1. Adsul, M.G.; Singhvi, M.S.; Gaikaiwari, S.A.; Gokhale, D.V. Development of biocatalysts for production of commodity chemicals from lignocellulosic biomass. Bioresour. Technol. 2011, 102, 4304-4312.

2. Nigam, P.S.; Singh, A. Production of liquid biofuels from renewable resources. Prog. Energy Combust. Sci. 2011, 37, 52-68.

3. Sindhu, R.; Kuttiraja, M.; Binod, P.; Janu, K.U.; Sukumaran, R.K.; Pandey, A. Dilute acid pretreatment and enzymatic saccharification of sugarcane tops for bioethanol production. Bioresour. Technol. 2011, 102, 10915-10921.

4. Dias, M.O.S.; Junqueira, T.L.; Cavalett, O.; Cunha, M.P.; Jesus, C.D.F.; Rossell, C.E.V.; Maciel-Filho, R.; Bonomi, A. Integrated versus stand-alone second generation ethanol production from sugarcane bagasse and trash. Bioresour. Technol. 2012, 103, 152-161. 
5. Seabra, J.E.A.; Tao, L.; Chum, H.L.; Macedo, I.C. A techno-economic evaluation of the effects of centralized cellulosic ethanol and co-products refinery options with sugarcane mill clustering. Biomass Bioenerg. 2010, 34, 1065-1078.

6. Amorim, H.V.; Lopes, M.L.; Oliveira, J.V.C.; Buckeridge, M.S.; Goldman, G.H. Scientific challenges of bioethanol production in Brazil. Appl. Microbiol. Biotechnol. 2011, 91, 1267-1275.

7. Alonso Pippo, W.; Luengo, C.A.; Alonsoamador Morales Alberteris, L.; Garzone, P.; Cornacchia, G. Energy recovery from sugarcane-trash in the light of 2 nd generation biofuels. Part 1: Current situation and environmental aspects. Waste Biomass Valor. 2011, 2, 1-16.

8. Gao, D.; Uppugundla, N.; Chundawat, S.P.; Yu, X.; Hermanson, S.; Gowda, K.; Brumm, P.; Mead, D.; Balan, V.; Dale, B.E. Hemicellulases and auxiliary enzymes for improved conversion of lignocellulosic biomass to monosaccharides. Biotechnol. Biofuels 2011, 4, 5:1-5:11, doi:10.1186/1754-6834-4-5.

9. Harris, D.; DeBolt, S. Synthesis, regulation and utilization of lignocellulosic biomass. Plant Biotechnol. J. 2010, 8, 244-262.

10. $\mathrm{Hu}, \mathrm{J}$.; Arantes, V.; Saddler, J.N. The enhancement of enzymatic hydrolysis of lignocellulosic substrates by the addition of accessory enzymes such as xylanase: Is it an additive or synergistic effect? Biotechnol. Biofuels 2011, 4, 36:2-36:13, doi:10.1186/1754-6834-4-36.

11. Dhillon, G.S.; Oberoi, H.S.; Kaur, S.; Bansal, S.; Brar, S.K. Value-addition of agricultural wastes for augmented cellulase and xylanase production through solid-state tray fermentation employing mixed-culture of fungi. Ind. Crop Prod. 2011, 34, 1160-1167.

12. Deswal, D.; Khasa, Y.P.; Kuhad, R.C. Optimization of cellulose production by a brown rot fungus Fomitopsis sp. RCK2010 under solid state fermentation. Bioresour Technol. 2011, 102, 6065-6072.

13. Qing, Q.; Yang, B.; Wyman, C.E. Xylooligomers are strong inhibitors of cellulose hydrolysis by enzymes. Bioresour. Technol. 2010, 101, 9624-9630.

14. Kumar, A.; Gupta, R.; Shrivastava, B.; Khasa, Y.P.; Kuhad, R.C. Xylanase production from an alkalophilic actinomycete isolate Streptomyces sp. RCK-2010, its characterization and application in saccharification of second generation biomass. J. Mol. Catal. B Enzym. 2012, 74, 170-177.

15. Lynd, L.R.; Weimer, P.J.; Zyl, W.H.; Pretorius, I.S. Microbial cellulose utilization: Fundamentals and biotechnology. Microbiol. Mol. Biol. Rev. 2002, 66, 506-77.

16. Bhatia, Y.; Mishra, S.; Bisaria, V.S. Microbial $\beta$-glucosidases: Cloning, properties, and applications. Crit. Rev. Biotechnol. 2002, 22, 375-407.

17. Knob, A.; Terrasan, C.R.F.; Carmona, E.C. $\beta$-Xylosidases from filamentous fungi: An overview. World J. Microbiol. Biotechnol. 2010, 26, 389-407.

18. Polizeli, M.L.; Rizzatti, A.C.S.; Monti, R.; Terenzi, H.F.; Jorge, J.A.; Amorin, D.S. Xylanases from fungi: Properties and industrial applications. Appl. Microbiol. Biotechnol. 2005, 67, 577-591.

19. Hölker U.; Höfer, M.; Lenz, J. Biotechnological advantages of laboratory-scale solid-state fermentation with fungi. Appl. Microbiol. Biotechnol. 2004, 64, 175-186.

20. Krishna, C. Solid-state fermentation systems: An overview. Crit. Rev. in Biotechnol. 2005, 25, 1-30.

21. Singhania, R.R.; Sukumaran, R.K.; Patel, A.K.; Larroche, C.; Pandey, A. Advancement and comparative profiles in the production technologies using solid-state and submerged fermentation for microbial cellulases. Enzyme Microb. Technol. 2010, 46, 541-549. 
22. Dean, R.; Van Kan, J.A.L.; Pretorius, Z.A.; Hammond-Kosack, K.E.; Di Pietro, A.; Spanu, P.D.; Rudd, J.J.; Dickman, M.; Kahmann, R.; Ellis, J.; Foster, G.D. The top 10 fungal pathogens in molecular plant pathology. Mol. Plant Pathol. 2012, 13, 414-430.

23. Sanchez, C. Lignocellulosic residues: Biodegradation and bioconversion by fungi. Biotechnol. Adv. 2009, 27, 185-194.

24. Zou, G.; Shi, S.; Jiang, Y.; van den Brink, J.; de Vries, R.P.; Chen, L.; Zhang, J.; Ma, L.; Wang, C.; Zhou, Z. Construction of a cellulase hyper-expression system in Trichoderma reesei by promoter and enzyme engineering. Microb. Cell Fact. 2012, 11, 21:1-21:12, doi:10.1186/1475-2859-11-21.

25. Suwannarangsee, S.; Bunterngsook, B.; Arnthong, J.; Paemanee, A.; Thamchaipenet, A.; Eurwilaichitr, L.; Laosiripojana, L.; Champreda, V. Optimisation of synergistic biomass-degrading enzyme systems for efficient rice straw hydrolysis using an experimental mixture design. Bioresour. Technol. 2012, 119, 252-261.

26. Kang, S.W.; Park, Y.S.; Lee, J.S.; Hong, S.I.; Kim, S.W. Production of cellulases and hemicellulases by Aspergillus niger KK2 from lignocellulosic biomass. Bioresour. Technol. 2004, 91, 153-156.

27. Masui, D.C.; Zimbardi, A.L.R.L.; Souza, F.H.M.; Guimarães, L.H.S.; Furriel, R.P.M.; Jorge, J.A. Production of a xylose-stimulated $\beta$-glucosidase and a cellulase-free thermostable xylanase by the thermophilic fungus Humicola brevis var. thermoidea under solid state fermentation. World J. Microbiol. Biotechnol. 2012, 28, 2689-2701.

28. Delabona, P.S.; Pirota, R.D.P.B.; Codima, C.A.; Tremacoldic, C.R.; Rodrigues, A.; Farinas, C.S. Effect of initial moisture content on two Amazon rainforest Aspergillus strains cultivated on agro-industrial residues: Biomass-degrading enzymes production and characterization. Ind. Crop. Prod. 2013, 42, 236- 242.

29. Souza, D.T.; Bispo, A.S.R.; Bon, E.P.S.; Coelho, R.R.R.; Nascimento, R.P. Production of thermophilic Endo- $\beta-1,4$-xylanases by Aspergillus fumigatus FBSPE-05 using agro-industrial by-products. Appl. Microbiol. Biotechnol. 2012, 166, 1575-1585.

30. Jatinder, K.; Chadha, B.S.; Saini, H.S. Regulation of cellulase production in two thermophilic fungi Melanocarpus sp. MTCC 3922 and Scytalidium thermophilum MTCC 4520. Enzyme Microb. Technol. 2006, 38, 931-936.

31. Leite, R.S.R.; Alves-Prado, H.F.; Cabral, H.; Pagnocca, F.C.; Gomes, E.; Da Silva, R. Production and characteristics comparison of crude b-glucosidases produced by microorganisms Thermoascus aurantiacus and Aureobasidium pullulans in agricultural wastes. Enzyme Microb. Technol. 2008, 43, 391-395.

32. Kasana, R.C.; Salwan, R.; Yadav, S.K. Microbial proteases: Detection, production, and genetic improvement. Crit. Rev. Microbiol. 2011, 37, 262-276.

33. Mamma, D.; Kourtoglou, E.; Christakopoulos, P. Fungal multienzyme production on industrial by-products of the citrus-processing industry. Bioresour. Technol. 2008, 99, 2373-2383.

34. Dogaris, I.; Vakontios, G.; Kalogeris, E.; Mamma, D.; Kekos, D. Induction of cellulases and hemicellulases from Neurospora crassa under solid-state cultivation for bioconversion of sorghum bagasse into ethanol. Ind. Crop. Prod. 2009, 29, 404-411. 
35. Delabona, P.S.; Pirota, R.D.P.B.; Codima, C.A.; Tremacoldi, C.R.; Rodrigues, A.; Farinas, C.S. Using Amazon forest fungi and agricultural residues as a strategy to produce cellulolytic enzymes. Biomass Bioenerg. 2012, 37, 243-250.

36. Jahromi, M.F.; Liang, J.B.; Rosfarizan, M.; Goh, Y.M.; Shokryazdan, P.; Ho, Y.W. Efficiency of rice straw lignocelluloses degradability by Aspergillus terreus ATCC 74135 in solid state Fermentation. Afr. J. Biotechnol. 2011, 10, 4428-4435.

37. Kalogeris, E.; Christakopoulos, P.; Kekos, D.; Macris, B.J. Studies on the solid-state production of thermostable endoxylanases from Thermoascus aurantiacus: Characterization of two isozymes. J. Biotechnol. 1998, 60, 155-163.

38. Gao, J.; Weng, H.; Xi, Y.; Zhu, D.; Han, S. Purification and characterization of a novel endo- $\beta$-1,4-glucanase from the thermoacidophilic Aspergillus terreus. Biotechnol. Lett. 2008, 30, $323-327$.

39. Ferreira, G.; Boer, C.G.; Peralta, R.M. Production of xylanolytic enzymes by Aspergillus tamarii in solid state fermentation. FEMS Microbiol. Lett. 1999, 173, 335-339.

40. Bokhari, S.A.I.; Latif, F.; Akhtar, M.W.; Rajoka, M.I. Characterization of a $\beta$-xylosidase produced by a mutant derivative of Humicola lanuginosa in solid state fermentation. Ann. Microbiol. 2010, 60, 21-29.

41. Oberoi, H.S.; Chavan, Y.; Bansal, S.; Dhillon, G.S. Production of cellulases through solid state fermentation using kinnow pulp as a major substrate. Food Bioprocess Technol. 2010, 3, 528-536.

42. Chandel, A.K.; Silva, S.S.; Carvalho, W.; Singh, O.V. Sugarcane bagasse and leaves: Foreseeable biomass of biofuel and bio-products. J. Chem. Technol. Biotechnol. 2012, 87, 11-20.

43. Farinas, C.S.; Loyo, M.M.; Baraldo, A., Jr.; Tardioli, P.W.; Bertucci Neto, V.; Couri, S. Finding stable cellulase and xylanase: Evaluation of the synergistic effect of $\mathrm{pH}$ and temperature. New Biotechnol. 2010, 27, 810-815.

44. Souza, F.H.M.; Nascimento, C.V.; Rosa, J.C.; Masui, D.C.; Leone, F.A.; Jorge, J.A.; Furriel, R.P.M. Purification and biochemical characterization of a mycelial glucose- and xylose-stimulated $\beta$-glucosidase from the thermophilic fungus Humicola insolens. Process Biochem. 2010, 45, 272-278.

45. Zanoelo, F.F.; Polizeli, M.L.T.M.; Terenzi, H.F.; Jorge, J.A. $\beta$-Glucosidase activity from the thermophilic fungus Scytalidium thermophilum is stimulated by glucose and xylose. FEMS Microbiol. Lett. 2004, 240, 137-143.

46. Filho, E.X.F. Purification and characterization of a $\beta$-glucosidase from solid-state cultures of Humicola grisea var. thermoidea. Can. J. Microbiol. 1996, 42, 1-5.

47. Nascimento, C.V.; Souza, F.H.M.; Masui, D.C.; Leone, F.A.; Peralta, R.M.; Jorge, J.A.; Furriel, R.P.M. Purification and biochemical properties of a glucose-stimulated $\beta$-D-glucosidase produced by Humicola grisea var. thermoidea grown on sugarcane bagasse. J. Microbiol. 2010, 48, 53-62.

48. Peralta, R.M.; Terenzi, H.F.; Jorge, J.A. $\beta$-D-Glycosidase activities of Humicola grisea: Biochemical and kinetic characterization of a multifunctional enzyme. Biochim. Biophys. Acta Gen. Subj. 1990, 1033, 243-249. 
49. Venturi, L.L.; Polizeli, M.L.; Terenzi, H.F.; Furriel, R.P.M.; Jorge, J.A. Extracellular $\beta$-D-glucosidase from Chaetomium thermophilum var. coprophilum: Production, purification and some biochemical properties. J. Basic Microbiol. 2002, 42, 55-66.

50. Leite, R.S.R.; Gomes, E.; Da-Silva, R. Characterization and comparison of termostability of purified $\beta$-glucosidases from a mesophilic Aureobasidium pullulans and a thermophilic Thermoacus aurantiacus. Process Biochem. 2007, 42, 1101-1106.

51. Almeida, E.M.; Polizeli, M.L.T.M.; Terenzi, H.F.; Jorge, J.A. Purification and biochemical characterization of $\beta$-xylosidase from Humicola grisea var. thermoidea. FEMS Microbiol. Lett. 1995, 130, 171-176.

52. Zanoelo, F.F.; Polizeli, M.L.T.M.; Terenzi, H.F.; Jorge, J.A. Purification and biochemical properties of a thermostable xylose-tolerant $\beta$-D-xylosidase from Scytalidium thermophilum. J. Ind. Microbiol. Biotechnol. 2004, 31, 170-176.

53. Matsuo, M.; Endou, A.; Okada, T.; Yamaoka, Y. Purification and characterization of $\beta$-xylosidase from Thermoascus sp. J. Ferment. Bioeng. 1998, 86, 403-405.

54. Iembo, T.; Azevedo, M.O.; Bloch Jr., C.; Filho, E.X.F. Purification and partial characterization of a new $\beta$-xylosidase from Humicola grisea var. thermoidea. World J. Microbiol. Biotechnol. 2006, $22,475-479$.

55. Katapodis, P.; Nerinckx, W.; Claeyssens, M.; Christakopoulos, P. Purification and characterization of a thermostable intracellular $\beta$-xylosidase from the thermophilic fungus Sporotrichum thermophile. Process Biochem. 2006, 41, 2402-2409.

56. Yan, Q.J.; Wang, L.; Jiang, Z.Q.; Yang, S.Q.; Zhu, H.F.; Li, L.T. A xylose-tolerant $\beta$-xylosidase from Paecilomyces thermophila: Characterization and its co-action with the endogenous xylanase. Bioresour. Technol. 2008, 99, 5402-5410.

57. Lucena-Neto, S.A.; Filho, E.X.F. Purification and characterization of a new xylanase from Humicola grisea var. thermoidea. Braz. J. Microbiol. 2004, 35, 86-90.

58. Damaso, M.C.T.; Andrade, C.M.M.C.; Pereira, P. Use of corncob for endoxylanase production by thermophilic fungus Thermomyces lanuginosus IOC-4145. Appl. Biochem. Biotechnol. 2000, 84-86, 821-834.

59. Vafiadi, C.; Christakopoulos, P.; Topakas, E. Purification, characterization and mass spectrometric identification of two thermophilic xylanases from Sporotrichum thermophile. Process Biochem. 2010, 45, 419-424.

60. Jiang, Z.; Cong, Q.; Yan, Q.; Kumar, N.; Dub, X. Characterization of a thermostable xylanase from Chaetomium sp. and its application in chinese steamed bread. Food Chem. 2010, 120, 457-462.

61. Khucharoenphaisan, K.; Tokuyama, S.; Kitpreechavanich, V. Purification and characterization of a high-thermostable b-xylanase from newly isolated Thermomyces lanuginosus THKU-49. Mycoscience 2010, 51, 405-410.

62. Romdhane, I.B.B.; Maaleja-Chouri, I.; Belghith, H. Improvement of highly thermostable xylanases production by Talaromyces thermophilus for the agro-industrial residue hydrolysis. Appl. Biochem. Biotechnol. 2010, 162, 1635-1646. 
63. Ferreira-Leitão, V.; Perrone, C.C.; Rodrigues, J.; Franke, A.P.M.; Macrelli, S.; Zacchi, G. An approach to the utilization of $\mathrm{CO}_{2}$ as impregnating agent in steam pretreatment of sugar cane bagasse and leaves for ethanol production. Biotechnol. Biofuels 2010, 3, 7:1-7:8, doi:10.1186/1754-6834-3-7.

64. Krishnan, C.; Sousa, L.C.; Jin, M.; Chang, L.; Dale, B.E.; Balan, V. Alkali-based AFEX pretreatment for the conversion of sugarcane bagasse and cane leaf residues to ethanol. Biotechnol. Bioeng. 2010, 107, 441-450.

65. Sant'Ana da Silva, A.; Inoue, H.; Endo, T.; Yano, S.; Bon, E.P.S. Milling pretreatment of sugarcane bagasse and straw for enzymatic hydrolysis and ethanol fermentation. Bioresour. Technol. 2010, 101, 7402-7409.

66. Barnett, H.L.; Hunter, B.B. Illustrated Genera of Imperfect Fungi, 4nd ed.; APS Press: St. Paul, MN, USA, 1998.

67. Schadeck, R.J.G.; Buchi, D.F.; Leite, B. Ultrastructural aspects of Colletotrichum graminicola conidium germination, apressorium formation and penetration on cellophane membranes: Focus on liped reserves. J. Submicrosc. Cytol. Pathol. 1998, 30, 555-561.

68. Miller, G.L. Use of dinitrosalicylic acid reagent for determination of reducing sugars. Anal. Chem. 1959, 31, 426-428.

69. Bergmeyer, H.U.; Bernt, E. Glucose Determination with Glucose Oxidase and Peroxidase. In Methods of Enzymatic Analysis; Bergmeyer, H.U., Ed.; Verlag Chimie-Academic Press: New York, NY, USA, 1974; Volume 3, pp. 1205-1215.

70. McIlvaine, T.C. A buffer solution for colorimetric comparison. J. Biol. Chem. 1921, 49, 183-186.

71. Read, S.M.; Northcote, D.H. Minimization of variation in the response to different protein of the Coomassie blue $\mathrm{G}$ dye-binding assay for protein. Anal. Biochem. 1981, 116, 53-64.

72. Sluiter, A.; Hames, B.; Ruiz, R.; Scarlata, C.; Sluiter, J.; Templeton Crocker, D. Determination of Structural Carbohydrates and Lignin in Biomass; Technical Report for Laboratory Analytical Procedure (LAP), National Renewable Energy Laboratory: Golden, CO, USA, April 2008.

(C) 2013 by the authors; licensee MDPI, Basel, Switzerland. This article is an open access article distributed under the terms and conditions of the Creative Commons Attribution license (http://creativecommons.org/licenses/by/3.0/). 